\title{
Distinct Transcriptomes Define Rostral and Caudal Serotonin Neurons
}

\author{
Christi J. Wylie, ${ }^{1}$ Timothy J. Hendricks, ${ }^{3}$ Bing Zhang, ${ }^{4}$ Lily Wang, ${ }^{5}$ Pengcheng Lu, ${ }^{4}$ Patrick Leahy, ${ }^{2}$ Stephanie Fox,${ }^{1}$ \\ Hiroshi Maeno, ${ }^{1}$ and Evan S. Deneris ${ }^{1}$ \\ ${ }^{1}$ Department of Neurosciences and ${ }^{2}$ Case Comprehensive Cancer Center, Case Western Reserve University, Cleveland, Ohio 44106, ${ }^{3}$ Molecular Neurobiology \\ Laboratory, Salk Institute for Biological Studies, La Jolla, California 92037, and Departments of ${ }^{4}$ Biomedical Informatics and ${ }^{5}$ Biostatistics, Vanderbilt \\ University School of Medicine, Nashville, Tennessee 37232
}

The molecular architecture of developing serotonin (5HT) neurons is poorly understood, yet its determination is likely to be essential for elucidating functional heterogeneity of these cells and the contribution of serotonergic dysfunction to disease pathogenesis. Here, we describe the purification of postmitotic embryonic $5 \mathrm{HT}$ neurons by flow cytometry for whole-genome microarray expression profiling of this unitary monoaminergic neuron type. Our studies identified significantly enriched expression of hundreds of unique genes in 5HT neurons, thus providing an abundance of new serotonergic markers. Furthermore, we identified several hundred transcripts encoding homeodomain, axon guidance, cell adhesion, intracellular signaling, ion transport, and imprinted genes associated with various neurodevelopmental disorders that were differentially enriched in developing rostral and caudal 5HT neurons. These findings suggested a homeodomain code that distinguishes rostral and caudal 5HT neurons. Indeed, verification studies demonstrated that Hmx homeodomain and Hox gene expression defined an $\mathrm{Hmx}^{+}$rostral subtype and $\mathrm{Hox}^{+}$caudal subtype. Expression of engrailed genes in a subset of 5HT neurons in the rostral domain further distinguished two subtypes defined as $\mathrm{Hmx}^{+} \mathrm{En}^{+}$and $\mathrm{Hmx}^{+} \mathrm{En}^{-}$. The differential enrichment of gene sets for different canonical pathways and gene ontology categories provided additional evidence for heterogeneity between rostral and caudal 5HT neurons. These findings demonstrate a deep transcriptome and biological pathway duality for neurons that give rise to the ascending and descending serotonergic subsystems. Our databases provide a rich, clinically relevant resource for definition of 5HT neuron subtypes and elucidation of the genetic networks required for serotonergic function.

\section{Introduction}

Genetic perturbation of embryonic brain serotonin (5HT) neuron gene expression causes developmental alterations in numerous rodent behaviors (Hendricks et al., 2003; Hodges et al., 2008; Lerch-Haner et al., 2008) and is thought to significantly contribute to susceptibility of human emotional and stress-related neurodevelopmental pathogenesis in adulthood (Ansorge et al., 2007). Evidence in support of these ideas is primarily derived from the study of genes encoding the rate-limiting biosynthetic enzyme tryptophan hydroxylase 2 (TPH2), the 5HT transporter (Sert), and the serotonin la autoreceptor (Leonardo and Hen, 2006; Holmes, 2008; Le François et al., 2008). As these proteins operate in complex networks of poorly defined cellular regulatory pathways (Prasad et al., 2005), many other genes are likely to be important for serotonergic function, and many of them may be relevant to human mental disease pathogenesis. Yet their iden-

Received Sept. 17, 2009; revised 0ct. 21, 2009; accepted Nov. 14, 2009.

This work was supported by National Institute of Mental Health Silvio Conte Center Grant P50 MH078028 (Project 1) to E.S.D. We thank Randy Blakely, Elaine Sanders-Bush, Doug McMahon, Ron Emeson, Pat Levitt, other members of Vanderbilt Conte Center, and Robert Miller in the Case Western Reserve University Neuroscience Department for helpful suggestions and comments on this project. We thank Kathy Lobur for help with timed pregnancies and genotyping. We thank A. Joyner and Brian Bai for pan-engrailed antiserum and T. Jessell for Hox antibodies.

Correspondence should be addressed to Evan S. Deneris, Department of Neuroscience, School of Medicine, Case Western Reserve University, 2109 Adelbert Road, Cleveland, OH 44106-4975. E-mail: esd@case.edu.

DOI:10.1523/JNEUROSCI.4656-09.2010

Copyright $\odot 2010$ the authors $\quad 0270-6474 / 10 / 300670-15 \$ 15.00 / 0$ tity is largely obscure in part because of a lack of an approach to isolate 5HT neurons for comprehensive gene expression profiling of this CNS cell type.

Gene expression profiles of 5HT neurons may be complex despite their common monoaminergic character if, as is evident, these cells are heterogeneous. 5HT neurons can be distinguished according to their axonal trajectories and physiological properties (Beck et al., 2004; Kocsis et al., 2006). Rostral 5HT neurons, born anterior to rhombomere $4(\mathrm{r} 4)$ give rise to ascending axonal projections, which modulate circuitry needed for emotional responses, circadian rhythms, and energy balance (Lucki, 1998; Sodhi and Sanders-Bush, 2004). A caudal cluster, posterior to r4 gives rise to descending pathways, which modulate a diversity of physiological processes including cardiorespiratory homeostasis, thermoregulation, and nociception (Mason, 2001; Erickson et al., 2007; Zhao et al., 2007; Gargaglioni et al., 2008; Hodges et al., 2008). Differences in progenitor identities (Jacob et al., 2007; Lillesaar et al., 2007), extrinsic signaling dependencies (Ye et al., 1998), transcription factor requirements (Hendricks et al., 2003), and distinct rhombomere-specific neuron sublineages (Jensen et al., 2008) suggest complexity in rostrocaudal serotonergic differentiation programs that generate these cells. These potentially distinct programs may direct different patterns of 5HT neuron gene expression and account for the diversity of behaviors and physiological processes under serotonergic modulation as well as the large number of neuropsychiatric disorders in which seroto- 

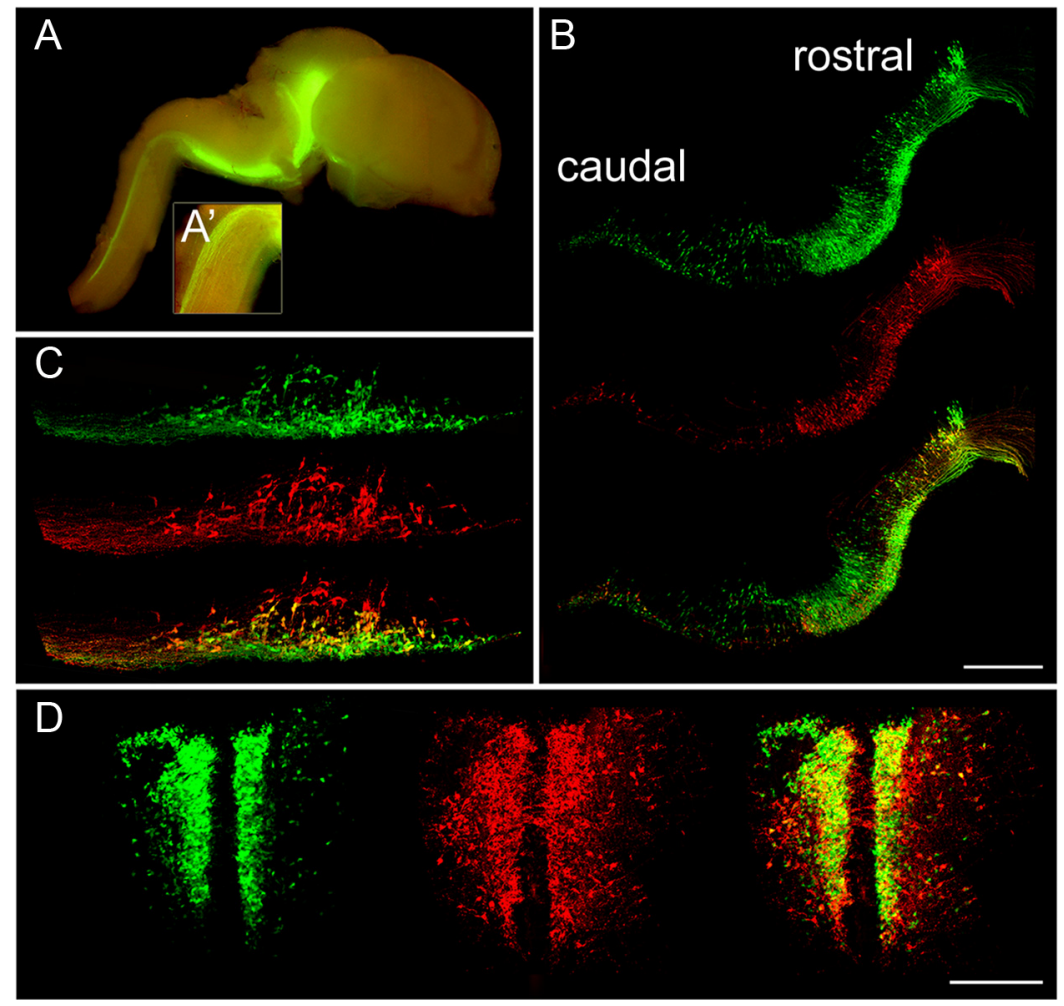

Figure 1. ePet-EYFP expression marks rostral and caudal $5 \mathrm{HT}$ neurons in the embryonic ventral hindbrain. $A$, Whole-mount view of an ePet-EYFP transgenic brain at E14.5. Both rostral and caudal 5HT neuronal cell bodies and axonal projections were brightly marked by EYFP fluorescence. $\boldsymbol{A}^{\prime}$, High-magnification view $(8 \times)$ of caudal $5 \mathrm{HT}$ axonal projections to the spinal cord. $\boldsymbol{B}$ - $\boldsymbol{D}$, Tiled confocal $z$-stack images of $5 \mathrm{HT}$ immunoreactivity (red) and EYFP fluorescence at E12.5 ( $\boldsymbol{B}$, sagittal view) and at E14.5 in the caudal ( $\boldsymbol{C}$, sagittal view) and rostral ( $\boldsymbol{D}$, coronal view) domains. Scale bars: $\boldsymbol{B}, 100 \mu \mathrm{m} ; \boldsymbol{C}, \boldsymbol{D}, 200 \mu \mathrm{m}$.

nergic dysfunction has been implicated (Holmes, 2008). Few genetic markers distinguish differentiated 5HT neurons, however, and therefore their molecular differences are poorly defined.

Whole-genome profiling is a powerful approach for analysis of molecular complexity in CNS neuronal and glia cell types and the developmental programs specifying their diversity (Sugino et al., 2006; Cahoy et al., 2008). Here, we report a purification protocol for enrichment of embryonic postmitotic 5HT neurons followed by microarray analysis of 5HT neuron gene expression profiles. Our microarray, verification, and bioinformatics studies identify several hundred genes and many biological pathways whose expression distinguishes rostral and caudal 5HT neurons. Our transcriptome datasets provide an abundance of new markers to enable molecular classification of 5HT neuron subtypes and a rich resource for identification of new serotonergic genes of potential relevance to mental disease pathogenesis.

\section{Materials and Methods}

Transgenic mice. ePet-EYFP mice were generated in a C57/SJL background. Embryos were genotyped either by PCR with primers 5'-GAA CTC CAG CAG GAC CAT GT- $3^{\prime}$ and 5' -TAT ATC ATG GCC GAC AAG CA-3' or by a fluorescence dissecting microscope.

Dissection of ePet-EYFP ${ }^{+}$neural tubes. Pregnant mice [embryonic day 0.5 (E0.5) defined as the morning of plug formation] were killed by cervical dislocation in accordance with Institutional Animal Care and Use Committee regulations. E12.5 embryos were removed from uteri into ice-cold L15 media (Invitrogen). Hindbrains were dissected and visualized under an inverted fluorescent dissecting microscope to identify ePet$\mathrm{EYFP}^{+}$transgenics. A nontransgenic embryo was identified and processed simultaneously as a negative control to gate for background fluorescence on the cell sorter. Hindbrains were dissected into rostral and caudal regions using the absence of YFP fluorescence in rhombomere 4 as a landmark. Specifically, the neural tube was isolated from the mesencephalic flexure to the spinal cord and cut at the pontine flexure to separate rostral and caudal hindbrain regions (see Fig. $2 A$ ).

Cell dissociation. Rostral and caudal hindbrains were enzymatically digested in $1 \times$ trypsin-EDTA (Invitrogen) diluted in $\mathrm{Ca}^{2+1}$ $\mathrm{Mg}^{2+}$-free DPBS (Invitrogen) at $37^{\circ} \mathrm{C}$ for 17 $\mathrm{min}$. Tissues were washed three times in icecold Leibovitz L15 media (Invitrogen). Samples were resuspended in L15 containing 0.1\% BSA (Invitrogen) and $0.1 \mu \mathrm{g} / \mathrm{ml}$ DNase (Sigma) and then mechanically dissociated by gentle trituration with a fire-polished glass pipette to create a single-cell suspension. Cells were pelleted and resuspended in L15 containing $0.1 \% \mathrm{BSA}$.

Flow cytometry. Cells were passed through a $40 \mu \mathrm{m}$ filter and immediately sorted on a Becton Dickinson FACS Aria digital cell sorter equipped with an argon laser providing excitation of $200 \mathrm{~mW}$ at $488 \mathrm{~nm}$. YFP fluorescence was detected with the standard FL2 filter set (560 $\mathrm{nm}$ dichroic, 585/42 $\mathrm{nm}$ bandpass). Sort pressure was 35 psi with an $85 \mu \mathrm{m}$ nozzle tip driven at $39.5 \mathrm{kHz}$. Maximum event rate was conservatively limited to 5000/s. Forward scatter height versus width gating was used to eliminate aggregates. YFP fluorescent cells were identified by characteristic red versus orange fluorescence and were sorted directly into tubes containing Trizol (Invitrogen) for subsequent RNA extraction or into L15 media for confirmation of sort purity. A typical sort with 4-5 transgenic embryos at E12.5 yielded $\sim 45,000$ rostral $\mathrm{YFP}^{+}$and 30,000 caudal $\mathrm{YFP}^{+}$5HT neurons. Using this protocol, we collected $\sim 200,000$ cells for each of the four cell groups to be

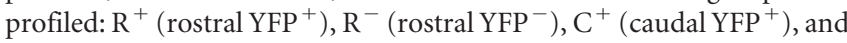
$\mathrm{C}^{-}$(caudal YFP ${ }^{-}$).

RNA isolation, amplification, and microarray hybridization. Total RNA was isolated after the addition of tRNA as carrier and RNA quality was inspected with a Bioanalyser 2100 (Agilent). One-round amplification was performed using the MessageAmp II Kit (Ambion). In vitro transcription with biotin incorporation (Bioarray High Yield RNA Transcript Labeling, Enzo) was used to generate cRNA probes. The quantity of cRNA was measured by Nanodrop 1000 (Nanodrop Technologies). Ten micrograms of cRNA for each cell type were fragmented and hybridized overnight at $42^{\circ} \mathrm{C}$ to Affymetrix whole-genome arrays (Mouse Genome 430 2.0). Each Affymetrix 4302.0 array contains 45,037 oligonucleotide probe sets, which represent 20,832 unique genes. After hybridization, the chips underwent stringency washes in a Genechip Fluidics Station (Affymetrix) and were scanned at high resolution (Affymetrix High Density GeneChip Scanner 3000). Three biological replicates from different litters, independent FACS isolation, amplification, and hybridization were performed to assess reproducibility. DAT files were later used to generate CEL files. Affymetrix GCOS using MAS 5.0 statistical algorithms was used to convert CEL files into Excel spread sheets. Standard quality assessment procedures were performed for all hybridizations according to Affymetrix recommendations.

Microarray data processing. Present/Absent calls for each probe set were calculated with Affymetrix MAS 5.0 package of Bioconductor (Reimers and Carey, 2006). Default parameters were used for the calculation. CEL files from 12 chips were normalized using the Robust MultiChip Averaging (RMA) algorithm as implemented in Bioconductor (Reimers and Carey, 2006).

Multiple-group comparison and hierarchical clustering. The ANOVA test in the Limma package (Smyth, 2005) was used to identify probe sets 
that were differentially expressed across the four test groups. The $p$ values generated from the ANOVA test were further adjusted using the Benjamini and Hochberg correction (Benjamini and Hochberg, 1995). In this comparison, differentially expressed probe sets were selected based on two criteria: (1) adjusted $p$ values $<0.001$, and (2) at least a twofold change between the groups with highest and lowest average expression values. Hierarchical clustering analysis (Eisen et al., 1998) was then applied to the selected probe sets. Average linkage was used in the clustering analysis with Pearson's correlation coefficient as the similarity measurement.

Pairwise comparisons. For pairwise comparisons, the $t$ test in the Limma package was used to identify differentially expressed probe sets between the two groups under comparison. The implementation of $t$ test in Limma uses an empirical Bayes method to moderate the SEs of the estimated log-fold changes. This results in more stable inference and improved power, especially for experiments with small number of arrays. The $p$ values generated from the $t$ test were further adjusted using the Benjamini and Hochberg correction (Benjamini and Hochberg, 1995) to account for multiple comparisons. An adjusted $p$ value of 0.01 (i.e., $1 \%$ false discovery rate) was used to select differentially expressed probe sets.

Knowledge-guided gene set-level analysis. We used the mixed models approach (Wang et al., 2008) to assess coordinated changes of genes at the gene set level in serotonin neurons. Gene sets derived from the Gene Ontology (GO) were downloaded from the Molecular Signatures Database (MSigDB) (http://www.broad. mit.edu/gsea/msigdb/index. jsp). For each gene set, this approach compares the average gene expression levels of the two groups (e.g., serotonin neurons vs nonserotonin neurons) for gene sets versus other genes while controlling for correlations between genes. Mixed models analysis uses continuous evidence from each gene so that the results do not depend on any significance cutoff for single genes as in conventional overrepresentation analysis. It was shown to have more favorable statistical properties compared to traditional gene set analysis methods (Wang et al., 2008). Because many gene sets were examined, to control for the rate of false-positive findings by chance, we adjusted nominal $p$ values using Bonferroni correction.

Double-label in situ hybridization/immunohistochemistry. DIG-labeled antisense probes were synthesized with digoxigenin-11-UTP according to the manufacturer's instructions (Roche). Tissues were fixed with $4 \%$ paraformaldehyde overnight and then cryoprotected in 30\% sucrose. Ten to twenty micrometer cryostat sections were collected on Superfrost Plus slides (Fisher). Sections were fixed again for $5 \mathrm{~min}$, washed three times with $1 \times$ PBS, treated with proteinase $\mathrm{K}(1 \mu \mathrm{g} / \mathrm{ml})$ for $3 \mathrm{~min}$, washed three times with $1 \times$ PBS, acetylated in $0.35 \%(\mathrm{v} / \mathrm{v})$ acetic anhydride at room temperature in $100 \mathrm{~mm}$ triethanolamine $\mathrm{pH} 8.0$ for 10 $\mathrm{min}$, and then rinsed three times in $1 \times$ PBS. Sections were prehybridized for $1 \mathrm{~h}$ at room temperature in hybridization buffer (50\% deionized formamide, $5 \times$ SSC, $5 \times$ Denhardt's solution, $250 \mu \mathrm{g} / \mathrm{ml}$ Baker's yeast tRNA, $500 \mu \mathrm{g} / \mathrm{ml}$ salmon sperm DNA). Probe was diluted 1:100 in hybridization buffer and applied to slides, which were then sealed with Hybrislip coverslips (Grace Biolabs). Hybridization was performed overnight at $65-68^{\circ} \mathrm{C}$. The next day coverslips were removed in $5 \times$ SSC. Sections were then washed for $2 \mathrm{~h}$ in $0.2 \times$ SSC at $65-68^{\circ} \mathrm{C}$. Sections were

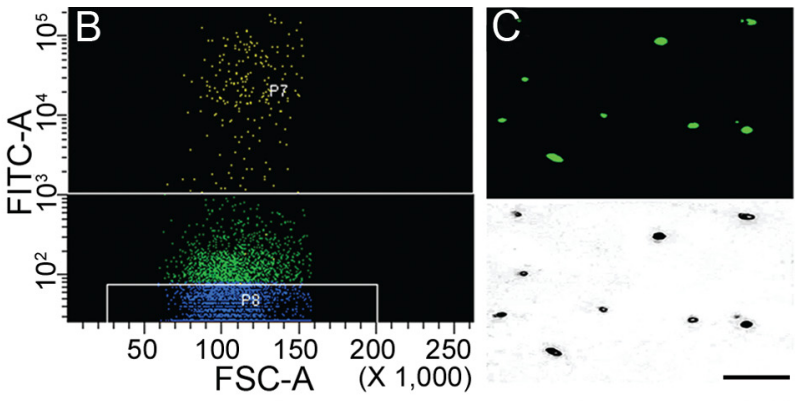

E

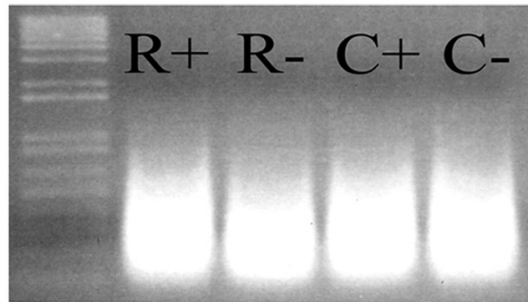

G

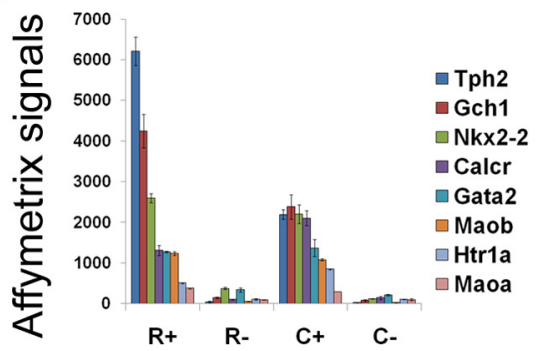

Figure 2. Purification and expression profiling of rostral and caudal 5HT neurons. A, E12.5 ePet-EYFP neural tubes were dissected and incisions made at the mesencephalic flexure, pontine flexure, and spinal cord to separate the rostral and cauda B, single-cell suspensions of rostral and caudal neural tubes were subjected to FACS. EYFP ${ }^{+}$cells were collected in gate $\left(\mathrm{R}^{-}\right)$, caudal YFP ${ }^{+}\left(\mathrm{C}^{+}\right)$, and caudal YFP ${ }^{-}\left(\mathrm{C}^{-}\right)$sorted cells and then assayed by Taqman RT-PCR for two known 5HT neuronspecific genes, Fev and Tph2. E, Total RNA from 200,000 sorted cells each for rostral $5 \mathrm{HT} \mathrm{YFP}^{+}\left(\mathrm{R}^{+}\right)$, rostral non-5HT $\left(\mathrm{R}^{-}\right)$, caudal detected in $\mathrm{R}^{+}$and $\mathrm{C}^{+}$neurons by microarray hybridization. The $y$-axis equals the gene expression level determined by MAS 5.0. Error bars represent SEM. Scale bars: $A, C, 100 \mu \mathrm{m}$.

then equilibrated in $1 \times \mathrm{B} 1(100 \mathrm{~mm}$ Tris, $\mathrm{pH} 7.4,150 \mathrm{~mm} \mathrm{NaCl})$ for 10 min, blocked for $1 \mathrm{~h}$ in $10 \%$ heat-inactivated goat serum diluted in $\mathrm{B} 1$, and then incubated overnight at $4^{\circ} \mathrm{C}$ with sheep anti-DIG-alkaline phosphatase-conjugated Fab fragments (Roche) diluted 1:5000 in blocking buffer. The next day slides were washed $3 \times 15 \mathrm{~min}$ in $1 \times \mathrm{B} 1$, equilibrated in freshly prepared B2 (300 mM Tris, pH 9.5, $300 \mathrm{~mm} \mathrm{NaCl}$, $150 \mathrm{mM} \mathrm{MgCl}_{2}$ ) for $10 \mathrm{~min}$, and then developed in chromogen solution containing $340 \mu \mathrm{g} / \mathrm{ml} \mathrm{NBT}, 180 \mu \mathrm{g} / \mathrm{ml} \mathrm{BCIP}$, and $240 \mu \mathrm{g} / \mathrm{ml}$ levamisole (all Sigma) in B2 at room temperature for $2-16 \mathrm{~h}$. For double labeling, slides were washed $3 \times 5 \mathrm{~min}$ in $1 \times$ PBS, blocked $1 \mathrm{~h}$ in $10 \%$ goat serum in $1 \times$ PBST, and incubated with anti-rabbit GFP (Clontech) at 1:1000 overnight at $4^{\circ} \mathrm{C}$. Sections were then washed $3 \times 5 \mathrm{~min}$ in $1 \times \mathrm{PBS}$ and incubated with a 1:1000 dilution of biotinylated goat anti-rabbit IgG antibody for $2 \mathrm{~h}$ at room temperature. Horseradish peroxidase staining was performed using the avidin-biotin-peroxidase complex (Vectastain ABC kit, Vector Laboratories) and SigmaFast DAB tablets (Sigma). Sections were dehydrated through graded ethanols and xylene and coverslipped with DPX (Electron Microscopy Sciences).

Immunohistochemistry and antibodies. Immunohistochemistry was performed on $20 \mu \mathrm{m}$ cryostat sections from embryos that were fixed in $4 \%$ PFA for $1-2 \mathrm{~h}$ and then cryoprotected in $30 \%$ sucrose. Pan-engrailed antiserum was a gift from Alexandra Joyner (Sloan-Kettering Institute). Hox antibodies were a gift from Thomas Jessell (Columbia University 
Medical Center). Pan-Meis antibody was a gift from Steve O'Gorman (Case Western Reserve University). Dilutions were 1:8000 for rabbit anti-HoxA3, 1:5000 for rabbit anti-HoxC4, 1:1000 for rabbit anti-panMeis, and 1:100 for rabbit anti-pan-engrailed antibodies. Goat antirabbit Texas Red secondary antibody (Jackson ImmunoResearch Laboratories) was used at 1:400.

Confocal microscopy. Twenty to thirty micrometer sections were imaged on a Zeiss LSM 510 Meta confocal microscope. For $z$-stacks, images were collected every $2-3 \mu \mathrm{m}$ and compressed using Zeiss LSM Image software.

Taqman quantitative real-time reverse transcription-PCR. Total RNA was extracted from FACS-isolated cells according to the Trizol method (Invitrogen). $\mathrm{R}^{+}, \mathrm{R}^{-}, \mathrm{C}^{+}$, and $\mathrm{C}^{-} \mathrm{RNA}$ samples were delivered to the Gene Expression and Genotyping Facility at Case Western Reserve. Samples were then converted to cDNA and then assayed by Taqman (Applied Biosystems) in triplicate for candidate gene confirmation. The $\mathrm{C}_{\mathrm{T}}$ (cycle number at threshold) was used to calculate the relative amounts of mRNA molecules for a given gene. The $C_{T}$ of each target gene was normalized by subtracting the $C_{T}$ value of the housekeeping gene $\beta$-actin, which gave the value $\Delta \mathrm{C}_{\mathrm{T}}$. The difference in the $\Delta \mathrm{C}_{\mathrm{T}}$ from the cell type of interest and a control cell type gave $\Delta \Delta \mathrm{C}_{\mathrm{T}}$. The relative quantitative change was shown as $2^{-\Delta \Delta \mathrm{C}_{\mathrm{T}}}$. Taqman assay IDs for each gene are as follows: Fev, Mm00462220 n1; Tph2, Mm00557717_m1; Rnf112 (Zfp179), Mm008396908_g1; Zcchc12, Mm00511603_m1; Tox, Mm00455231_m1; 2010204K13RIK, Mm01971390_s1; AW551984, Mm00724626_m1; 1700042O10RIK, Mm01191108_m1; Hmx2, Mm01165724_m1; Hmx3, Mm00433957_g1; Pou3f1, Mm00843534_s1; En1, Mm00438709_m1; En2, Mm00438710_m1; HoxA3, Mm01326402_m1; HoxB3, Mm00650701_m1; HoxD3, Mm00439371_m1; HoxA4, Mm01335255_g1; HoxB4, Mm00957964_ m1; HoxC4, Mm00442838_m1; HoxA5, Mm00439362_m1; HoxB5, Mm00657672_m1; HoxC5, Mm00433971_m1.

\section{Results \\ Purification and gene expression profiling of embryonic rostral and caudal 5HT neurons}

The ePet-EYFP transgenic mouse line expresses enhanced yellow fluorescent protein (EYFP) specifically in adult 5HT neurons (Scott et al., 2005). To determine whether this line would be suitable for identification and purification of embryonic 5HT neurons we determined the pattern of EYFP expression in the developing hindbrain. Both rostral and caudal embryonic 5HT neurons and their axons could be readily visualized by expression of YFP in the ePet-EYFP line (Fig. 1 and data not shown). YFP was colocalized with 5HT immunoreactivity but was not detected elsewhere in the hindbrain (Fig. $1 B-D$ and data not shown) consistent with endogenous Pet-1 expression (Hendricks et al., 1999). As expected, there was an absence of EYFP fluorescence in rhombomere 4 where 5HT neurons are not generated (Fig. $1 A$ ). Thus, the embryonic expression pattern of the ePet-EYFP line indicated that it could be used for identification and purification by flow cytometry of differentiating $5 \mathrm{HT}$ neurons from the rostral and caudal hindbrain.

We chose to profile gene expression at E12.5 when 5HT neurons are actively differentiating and cell migration and axon pathfinding are underway. At this developmental stage virtually all rostral 5HT neurons have differentiated (Pattyn et al., 2003). However, in the caudal hindbrain 5HT neuron differentiation is not yet complete at E12.5 and therefore the serotonergic cells at this stage are a mixture of postmitotic precursors and mature 5 HT neurons. Rostral and caudal hindbrain domains were dissected from E12.5 ePet-EYFP embryos (Fig. 2A), dissociated with trypsin digestion and triturated in preparation for flow cytometry. For each sort (Fig. 2 B), we also collected rostral YFP ${ }^{-}\left(\mathrm{R}^{-}\right)$ and caudal $\mathrm{YFP}^{-}\left(\mathrm{C}^{-}\right)$reference cells, which comprise primarily neighboring hindbrain motoneurons and interneurons. The purity of sorted $\mathrm{R}^{+}$and $\mathrm{C}^{+}$neurons was analyzed by examining a

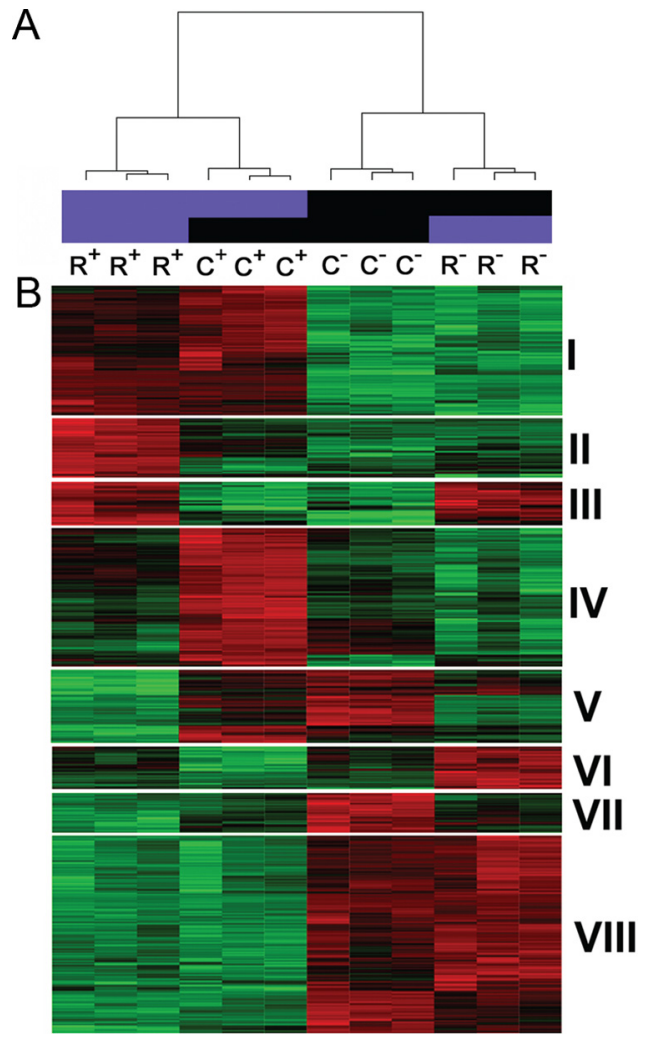

Figure 3. Unsupervised hierarchical clustering of serotonergic gene expression. $\boldsymbol{A}$, Dendrogram showing unsupervised hierarchical clustering of $\mathrm{R}^{+}, \mathrm{C}^{+}, \mathrm{R}^{-}$, and $\mathrm{C}^{-}$gene expression profiles from the 12 arrays. Biological replicates show a high degree of reproducibility. $\boldsymbol{B}$, Heat map displays eight distinct clusters of enriched gene expression in $\mathrm{R}^{+}, \mathrm{C}^{+}, \mathrm{R}^{-}$, and $\mathrm{C}^{-}$cell populations atE12.5. Each row represents the relative levels of expression for a single gene. The red or green color indicates high or low expression, respectively. Each column shows the expression profile for a single biological sample. Cluster I, Enriched gene expression in rostral $5 \mathrm{HT}$ and caudal 5HT neurons $\left(\mathrm{R}^{+} \mathrm{C}^{+}\right)$; cluster II, enriched gene expression in rostral 5HT neurons $\left(\mathrm{R}^{+}\right)$; cluster III, enriched gene expression in rostral $5 \mathrm{HT}$ and rostral non-5HT neurons $\left(\mathrm{R}^{+} \mathrm{R}^{-}\right)$; cluster IV, enriched gene expression in caudal $5 \mathrm{HT}$ neurons $\left(\mathrm{C}^{+}\right)$; cluster $\mathrm{V}$, enriched gene expression in caudal $5 \mathrm{HT}$ and caudal non-5HT neurons $\left(\mathrm{C}^{+} \mathrm{C}^{-}\right)$; cluster $\mathrm{VI}$, enriched gene expression in rostral non-5HT neurons $\left(\mathrm{R}^{-}\right)$; cluster VII, enriched gene expression in caudal non-5HT neurons $\left(\mathrm{C}^{-}\right)$; and cluster VIII, enriched gene expression in rostral and caudal non-5HT neurons $\left(\mathrm{R}^{-} \mathrm{C}^{-}\right)$.

portion of the cells under fluorescence and phase contrast microscopy to determine the number of cells that were also $\mathrm{YFP}^{+}$ (Fig. 2C). Approximately $98 \%$ of rostral and caudal cells were $\mathrm{YFP}^{+}$using our sorting parameters. We confirmed the purity of our sorted 5HT neurons by assaying for the expression of Fev (Pet-1) and Tph2, two genes whose expression in the CNS is restricted to $5 \mathrm{HT}$ neurons. Taqman real-time reverse transcription (RT)-PCR analyses of $\mathrm{R}^{+}, \mathrm{C}^{+}, \mathrm{R}^{-}$, and $\mathrm{C}^{-}$total RNAs showed at least a 10-fold enrichment of Fev and Tph2 in $\mathrm{R}^{+}$and $\mathrm{C}^{+}$relative to $\mathrm{R}^{-}$and $\mathrm{C}^{-}$(Fig. $2 \mathrm{D}$ ).

Probes (Fig. 2E) were generated from 200,000 sorted rostral and caudal $\mathrm{YFP}^{+}$cells and hybridized to Affymetrix 4302.0 arrays. These hybridizations were used to generate present/absent (P/A) calls as described in the Materials and Methods. An annotated master list of expression signals and P/A calls for all 12 array profiles is presented in Dataset 1 (available at www.jneurosci.org as supplemental material). The data discussed in this publication have been deposited in the NCBI Gene Expression Omnibus (GEO) and are accessible through GEO Series accession number GSE19474 (http://www.ncbi.nlm.nih.gov/geo/query/acc.cgi?acc= GSE19474). We first analyzed our dataset to confirm that known 
Table 1. Top 50 genes with enriched expression in $\mathrm{R}^{+} \mathrm{C}^{+} 5 \mathrm{HT}$ neurons (cluster $\mathrm{I}$ )

\begin{tabular}{|c|c|c|c|}
\hline Affy ID & Fold change & Gene symbol & Gene title \\
\hline 1430105_at & 19.9 & 1700042010Rik & RIKEN CDNA 1700042010 gene \\
\hline 1433434_at, 1433435_at & $18.6,7.1$ & AW551984 & Expressed sequence AW551984 \\
\hline 1460303_at, 1421867_at & $14.8,5.3$ & $\mathrm{Nr} 3 \mathrm{C} 1$ & Nuclear receptor subfamily 3 , group C, member 1 \\
\hline 1427038_at & 10.9 & Penk1 & Preproenkephalin 1 \\
\hline 1445546_at & 10.8 & Al844685 & Expressed sequence Al844685 \\
\hline 1445247_at & 9.9 & C530044C16Rik & RIKEN cDNA C530044C16 gene \\
\hline 1460578_at & 9.6 & Fgd5 & FYVE, RhoGEF, and PH domain-containing 5 \\
\hline 1421498_a_at & 9.4 & 2010204K13Rik & RIKEN CDNA 2010204K13 gene \\
\hline 1433578_at & 8.9 & EG545758 & Predicted gene, EG545758/solute carrier family 10 (sodium/bile acid cotransporter family), member 4 \\
\hline 1436004_at & 8.7 & Usp27x & Ubiquitin-specific peptidase $27, \mathrm{X}$ chromosome \\
\hline 1456108_x_at, 1418360_at, 1418360_at & $8.5,4.7,4.2$ & Rnf112 & Ring finger protein 112 \\
\hline 1440891_at, 1435722_at & $8.2,6.2$ & Gria4 & Glutamate receptor, ionotropic, AMPA4 ( $\alpha 4)$ \\
\hline 1458230_at & 7.1 & 一 & - \\
\hline 1450344_a_at & 7.0 & Ptger3 & Prostaglandin E receptor 3 (subtype EP3) \\
\hline 1441330_at & 6.9 & Crb1 & Crumbs homolog 1 (Drosophila) \\
\hline 1436772_at & 6.7 & - & - \\
\hline 1424842_a_at & 6.6 & Arhgap24 & Rho GTPase-activating protein 24 \\
\hline 1455416_at & 6.1 & C130021I20Rik & Riken cDNA C130021120 gene \\
\hline 1420955_at & 5.9 & Vsnl1 & Visinin-like 1 \\
\hline 1452981_at, 1449563_at & $5.8,5.1$ & Cntn1 & Contactin 1 \\
\hline 1441729_at & 5.6 & - & - \\
\hline 1456712_at, 1455260_at & $5.5,4.4$ & Lcorl & Ligand-dependent nuclear receptor corepressor-like \\
\hline 1447707_s_at, 1452202_at & $5.4,3.9$ & Pde2a & Phosphodiesterase 2A, cGMP-stimulated \\
\hline 1460097_at & 5.3 & - & - \\
\hline 1428434_at & 5.2 & Zcchc12 & Zinc finger, CCHC domain-containing 12 \\
\hline 1447669_s_at & 5.2 & Gng4 & Guanine nucleotide-binding protein (G-protein), $\gamma 4$ \\
\hline 1435939_s_at & 5.1 & Hepacam2 & HEPACAM family member 2 \\
\hline 1417441_at & 5.1 & Dnajc12 & DnaJ (Hsp40) homolog, subfamily C, member 12 \\
\hline 1447946_at & 4.9 & Adam23 & A disintegrin and metallopeptidase domain 23 \\
\hline 1441625_at & 4.9 & Rimbp2 & RIMS-binding protein 2 \\
\hline 1428599_at & 4.8 & Kndc1 & Kinase noncatalytic C-lobe domain (KIND)-containing 1 \\
\hline 1456783_at & 4.7 & Zdbf2 & Zinc finger, DBF-type-containing 2 \\
\hline 1434800_at & 4.7 & Sv2b & Synaptic vesicle glycoprotein 2 b \\
\hline 1441055_at & 4.4 & Akap2/Palm2 & A kinase (PRKA) anchor protein 2/paralemmin 2/Palm2-Akap2 protein \\
\hline 1419200_at & 4.3 & Fxyd7 & FXYD domain-containing ion transport regulator 7 \\
\hline 1433884_at & 4.3 & Syt1 & Synaptotagmin I \\
\hline 1416762_at, 1456642_x_at & $4.3,4.0$ & S100a10 & S100 calcium-binding protein A10 (calpactin) \\
\hline 1433643_at & 4.2 & Cacna2d1 & Calcium channel, voltage-dependent, $\alpha 2 / \delta$ subunit 1 \\
\hline 1429702_at & 4.1 & 2900072G11Rik & RIKEN CDNA 2900072 G11 gene \\
\hline 1426622_a_at & 4.0 & Qpct & Glutaminyl-peptide cyclotransferase (glutaminyl cyclase) \\
\hline 1442077_at & 4.0 & 2310076G05Rik & RIKEN cDNA 2310076G05 gene \\
\hline 1433582_at & 3.9 & 1190002N15Rik & RIKEN cDNA 1190002N15 gene/hypothetical protein LOC100044725 \\
\hline 1451046_at & 3.9 & LOC100047651 & Similar to FOG/zinc finger protein, multitype 1 \\
\hline 1417398_at, 1448689_at & $3.8,3.6$ & Rras2 & Related RAS viral (r-ras) oncogene homolog 2 \\
\hline 1452114_s_at & 3.7 & $\operatorname{lgfbp5}$ & Insulin-like growth factor-binding protein 5 \\
\hline 1433919_at & 3.7 & Asb4 & Ankyrin repeat and SOCS box-containing 4 \\
\hline 1452936_at & 3.7 & Crtac1 & Cartilage acidic protein 1 \\
\hline 1428221_at & 3.7 & Klhdc8b & Kelch domain-containing 8B \\
\hline 1417411_at & 3.6 & Nap115 & Nucleosome assembly protein 1-like 5 \\
\hline 1447933_at & 3.5 & Kif26a & Kinesin family member 26A \\
\hline
\end{tabular}

serotonergic genes were reproducibly detected. The arrays confirmed the enriched expression of 15 known serotonergic genes in $\mathrm{R}^{+}$and $\mathrm{C}^{+}$relative to $\mathrm{R}^{-}$and $\mathrm{C}^{-}$(Fig. $2 F, G$ ). Average signal intensities for these known 5HT neuron expressed genes ranged from 15,154 for probe set, 1435750_at, representing the GTP cyclohydrolase feedback regulator (Gchfr) to 335 for one of the probe sets, 1442676_at, that represents monoamine oxidase A (MaoA). We note, however, that our array studies failed to detect expression of some genes known to be expressed in 5HT neurons such as those encoding the htrlb receptor and $\alpha 1 \mathrm{~b}$ adrenergic receptor. The reason for these discrepancies is unclear but may reflect immature levels of expression at E12.5. Nevertheless, the detection of the majority of the traditional 5HT neuron markers further indicates that the process of hindbrain dissociation and flow cytometry did not result in qualitative changes in the phenotype of these purified cells and therefore supports strong confidence in our approach for discovery of serotonergic gene expression.

We next analyzed the array data to assemble 5HT neuron gene expression profiles. 5HT neuron development and function depends on the activity of broadly expressed genes such as housekeeping genes as well as genes whose expression is highly selective for 5HT neurons such as Fev or TPH2. Thus, our first goal was to assemble a list of all genes expressed in E12.5 5HT neurons without consideration of their possible enrichment in $\mathrm{R}^{+}$and $\mathrm{C}^{+}$cell groups. We based our conservative estimate of the number of 

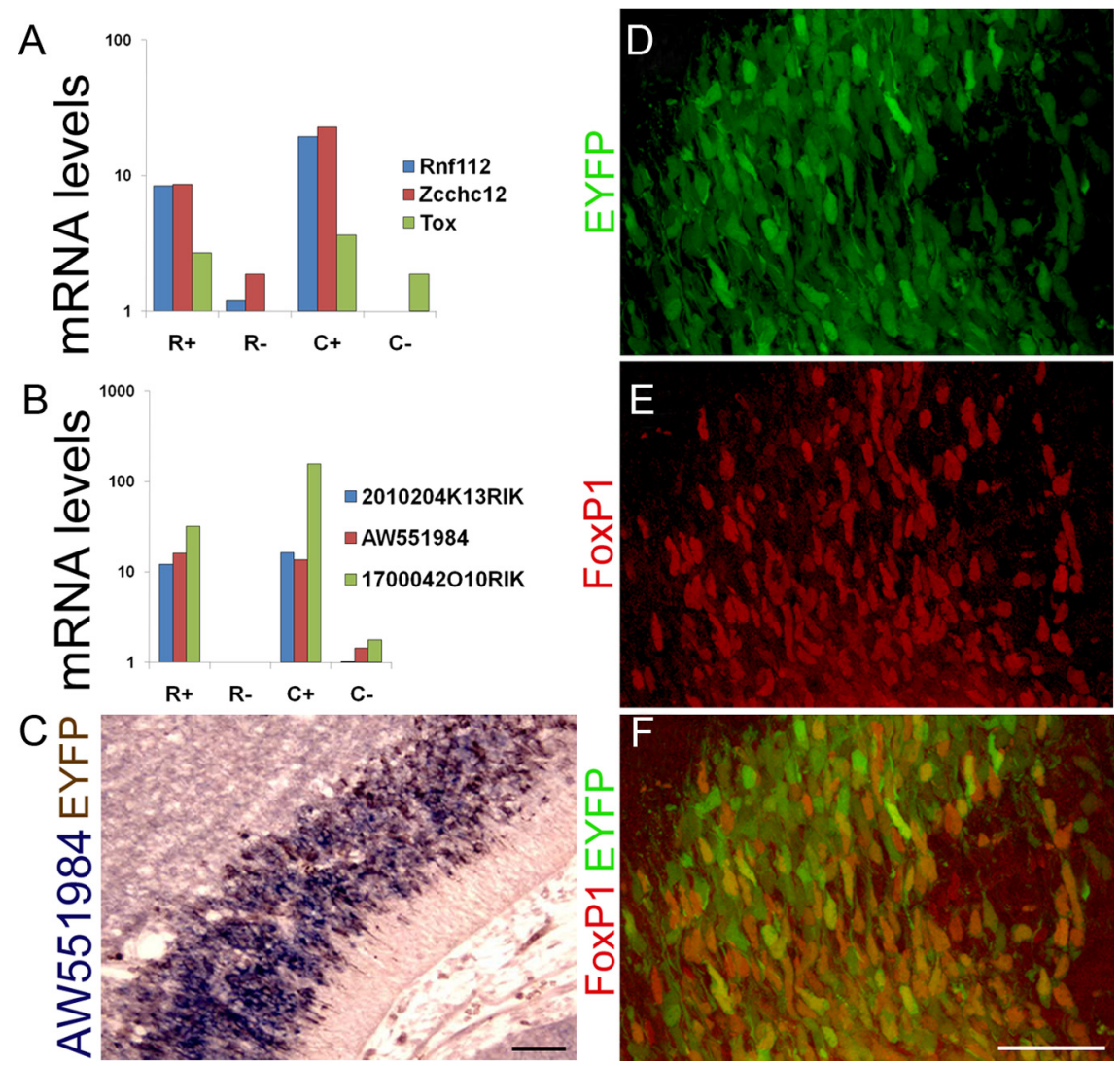

Figure 4. Verification of $5 H T$ neuron-enriched gene expression. $A, B$, Taqman RT-PCR verified $5 H T$ neuron-enriched expression of transcription factors Rnf112, Zcchc12, Tox and RIKEN genes 2010204K13Rik, AW551984, and 1700042010Rik. C, Double-label immunohistochemistry for EYFP (brown) and in situ hybridization for AW551984 transcript (purple) verified the enriched expression of est AW551984 in $5 H T$ neurons. $\boldsymbol{D}-\boldsymbol{F}$, Coimmunohistochemical staining of E12.5 neural tube confirmed FoxP1 (E) expression in YFP ${ }^{+}(\boldsymbol{D}) 5 \mathrm{HT}$ neurons $(\boldsymbol{F}$, overlay). Scale bars: $\boldsymbol{C}, 40 \mu \mathrm{m} ; \boldsymbol{D}-\boldsymbol{F}, 100 \mu \mathrm{m}$.

unique genes expressed in E12.5 5HT neurons on the number of probe sets in Dataset 1 (available at www.jneurosci.org as supplemental material) whose expression was reproducibly detected at a selected minimum threshold signal intensity level. Expression of a probe set was considered reproducibly detected if it was scored as present $(\mathrm{P})$ in all three biological replicates of $\mathrm{R}^{+}$or $\mathrm{C}^{+}$ profiles. The threshold signal intensity was set to the level of signal intensity for monoamine oxidase A probe set 1442676_at, whose mean expression level (335) was lowest of all probe sets for known serotonergic genes (Fig. 2G). Using these criteria, we estimated 12,559 probe sets were expressed in $\mathrm{R}^{+} \mathrm{C}^{+}$cells, which corresponds to 8186 individual genes, 866 RIKEN cDNAs and 435 ESTs. A database of E12.5 5HT neuron expressed genes with respective mean signal intensity levels in $\mathrm{R}^{+}$and $\mathrm{C}^{+}$is available in Dataset 2 (available at www.jneurosci.org as supplemental material). A search of the Allen Institute Brain Atlas (Ng et al., 2009) revealed 250 genes with a $\mathrm{TPH} 2$-like expression pattern in the adult brain (supplemental Table S1, available at www.jneurosci. org as supplemental material). We detected expression of 155 of these genes in $\mathrm{R}^{+}$and $\mathrm{C}^{+}$, indicating that many but not all TPH2like genes initiate expression during embryogenesis.

A major aim of this study was to identify new potential transcriptional determinants of 5HT neuron development. Therefore, we searched our list of 5HT neuron expressed genes according to protein molecular function and identified $>800$ genes encoding DNA binding proteins (supplemental Table S2, available at www.jneurosci.org as supplemental material). The complex innervation patterns of serotonergic axons that initiate around E12.5 led us to search for genes encoding axon pathfinding/cell adhesion molecules and 191 such genes were identified as expressed in $\mathrm{R}^{+}$and $\mathrm{C}^{+}$(supplemental Table S3, available at www.jneurosci.org as supplemental material). Finally, the neurochemically rich afferent input to $5 \mathrm{HT}$ neurons and the prominent role of the 5HT system in maintenance of homeostatic states prompted a search for genes encoding ion transport proteins, receptors and kinases. These searches uncovered 65 ion channel genes (supplemental Table S4, available at www.jneurosci.org as supplemental material), 118 solute carrier genes (supplemental Table S5, available at www. jneurosci.org as supplemental material), 38 G-protein-coupled receptors (supplemental Table S6, available at www.jneurosci.org as supplemental material), and 175 unique kinases (supplemental Table S7, available at www.jneurosci.org as supplemental material) expressed in $\mathrm{R}^{+}$and $\mathrm{C}^{+}$.

\section{HT neuron-enriched gene expression}

We next sought to determine differentially expressed genes in our four groups of profiled cell populations. Using the ANOVA test, we found 1806 probe sets that were differentially expressed across the four groups based on the criteria described in the Material and Methods. Unsupervised hierarchical clustering was applied to reveal clusters of biological samples and clusters of genes with similar expression patterns (Fig. 3). As shown in the dendrogram in Figure $3 A$, two distinct sample clusters were identified that correspond to the serotonergic and nonserotonergic cell groups we examined. Interestingly, the six serotonergic profiles sorted into two subclusters that correspond to the rostrocaudal origins of serotonin neurons, thus providing the first clear indication of large gene expression differences in rostral and caudal serotonin neurons. Not surprisingly, however, rostral and caudal serotonin neurons were more similar to each other than to nonserotonergic neurons from the same rostrocaudal level, while profiles of rostral and caudal nonserotonergic neurons were more similar to each other than to those of serotonergic neurons. Biological replicates for each of the different cell groups showed the highest similarities in gene expression patterns, thus further demonstrating the high reproducibility of our overall profiling method.

Hierarchical clustering of the genes revealed eight distinct gene expression clusters (I-VIII) that segregated according to serotonergic identity and rostrocaudal positions (Fig. 3B). Clusters $\mathrm{I}-\mathrm{V}$ comprise unique profiles of $\sim 800$ transcripts differentially enriched in $\mathrm{R}^{+}$and $\mathrm{C}^{+}$serotonin neurons, while clusters VI-VIII comprise transcripts enriched in $\mathrm{R}^{-}$and $\mathrm{C}^{-}$nonserotonergic reference cell populations.

We systematically examined each of the five serotonergic clusters to identify prominent molecular features of 5HT neuron transcriptomes. Cluster I is comprised of 317 probe sets corresponding to 274 unique transcripts enriched in both rostral 
Table 2. Gene ontology and pathway enrichment in $\mathrm{R}^{+} \mathrm{C}+5 \mathrm{HT}$ neurons

\begin{tabular}{|c|c|c|c|c|}
\hline Code & Gene set name & Size & $\mathrm{R}^{+}$Bon & $\mathrm{C}^{+}$Bon \\
\hline \multicolumn{5}{|c|}{ Biological process-enriched gene sets } \\
\hline 310 & Lipid metabolic process & $195 / 271$ & 0.002807 & $8.72 \times 10^{-6}$ \\
\hline 125 & Ceramide metabolic process & $7 / 10$ & 0.011107 & 0.003837 \\
\hline 62 & Calcium ion transport & $12 / 24$ & 0.017271 & $2.07 \times 10^{-5}$ \\
\hline 765 & Sphingolipid metabolic process & $12 / 24$ & 0.041981 & 0.0021 \\
\hline 573 & Proteolysis & $78 / 162$ & $1.87 \times 10^{-5}$ & $3.94 \times 10^{-9}$ \\
\hline 561 & Protein processing & $19 / 42$ & 0.03184 & 0.01963 \\
\hline 335 & Membrane lipid metabolic process & $36 / 88$ & 0.008563 & 0.000265 \\
\hline 246 & G-protein-coupled receptor protein signaling pathway & $101 / 290$ & 0.000209 & 0.003268 \\
\hline 557 & Protein modification process & $214 / 567$ & $2.02 \times 10^{-7}$ & $5.86 \times 10^{-6}$ \\
\hline 456 & Peptide metabolic process & $5 / 9$ & $7.1 \times 10^{-6}$ & 0.682079 \\
\hline 763 & Sphingoid metabolic process & $9 / 11$ & 0.055297 & 0.015825 \\
\hline 168 & Di-, trivalent inorganic cation transport & $17 / 29$ & 0.152911 & 0.000429 \\
\hline 86 & Cellular lipid metabolic process & $116 / 212$ & 0.05149 & 0.001441 \\
\hline 338 & Metal ion transport & $53 / 102$ & 1 & 0.00036 \\
\hline 74 & Cation transport & $62 / 128$ & 0.138503 & $7.68 \times 10^{-5}$ \\
\hline 555 & Protein metabolic process & $514 / 1066$ & 0.134745 & 0.000225 \\
\hline 296 & Ion transport & 75/161 & 1 & 0.001533 \\
\hline \multicolumn{5}{|c|}{ Cellular component-enriched gene sets } \\
\hline 232 & Voltage-gated calcium channel complex & $12 / 15$ & $1.49 \times 10^{-5}$ & 0.04144 \\
\hline 103 & Intrinsic to membrane & $387 / 1169$ & $2.76 \times 10^{-11}$ & $3.1 \times 10^{-13}$ \\
\hline 92 & Integral to plasma membrane & $275 / 846$ & $2.79 \times 10^{-5}$ & $7.08 \times 10^{-6}$ \\
\hline 193 & Protein complex & $176 / 703$ & $6.86 \times 10^{-7}$ & $1.28 \times 10^{-6}$ \\
\hline \multicolumn{5}{|c|}{ Molecular function-enriched gene sets } \\
\hline 393 & Voltage-gated channel activity & $32 / 66$ & 0.000161 & $5.47 \times 10^{-6}$ \\
\hline 102 & Exopeptidase activity & $13 / 28$ & 0.001926 & $5.75 \times 10^{-5}$ \\
\hline 30 & ATPase activity coupled to transmembrane movement of ions & $10 / 22$ & 0.041303 & 0.03688 \\
\hline 159 & Ion channel activity & $57 / 126$ & 0.000252 & $7.01 \times 10^{-9}$ \\
\hline 160 & Ion transmembrane transporter activity & $94 / 245$ & 0.011539 & $2.22 \times 10^{-7}$ \\
\hline 50 & Carboxypeptidase activity & $4 / 12$ & 0.033525 & 0.041814 \\
\hline 201 & Neuropeptide hormone activity & $5 / 10$ & 0.016866 & 1 \\
\hline 18 & Aminopeptidase activity & $9 / 10$ & 1 & 0.000943 \\
\hline 314 & Serine-type peptidase activity & $26 / 41$ & 0.277263 & $2.87 \times 10^{-5}$ \\
\hline 312 & Serine-type endopeptidase activity & $22 / 37$ & 0.889975 & $8.5 \times 10^{-5}$ \\
\hline 55 & Cation transmembrane transporter activity & $100 / 194$ & 0.053817 & $3.06 \times 10^{-6}$ \\
\hline \multicolumn{5}{|c|}{ Canonical pathway-enriched gene sets } \\
\hline 509 & RAB pathway & $9 / 10$ & $6.33 \times 10^{-7}$ & 0.000801 \\
\hline 454 & Nos1 pathway & $15 / 20$ & 0.001063 & 0.00845 \\
\hline 249 & HSA00600 sphingolipid metabolism & $18 / 31$ & 0.00138 & 0.022235 \\
\hline 244 & HSA00564 glycerophospholipid metabolism & $32 / 68$ & 0.002839 & 0.000696 \\
\hline
\end{tabular}

Bon, Bonferroni-corrected $p$ value.

and caudal 5HT neurons (supplemental Table S8, available at www.jneurosci.org as supplemental material). Only 13 of these genes have been shown by the Allen Institute to have a TPH2-like expression pattern in the adult brain. Further filtering of the cluster I list to exclude additional known serotonergic genes revealed 250 new genes with severalfold enrichment in $\mathrm{R}^{+}$and $\mathrm{C}^{+}$cells, thus validating our approach for discovery of 5HT neuron gene expression in the developing hindbrain (Table 1). Several of these potential new markers of developing 5HT neurons have well defined functions in other neural and non-neural cell types, while the function of others have not been elucidated.

Because of our interest in genes controlling 5HT neuron development, we focused our enrichment verification studies primarily on genes encoding known and putative transcriptional regulators. The genes we selected for confirmation spanned the full range of probe set signal intensities (1350-15,000) (supplemental Table S8, available at www.jneurosci.org as supplemental material). Taqman RT-PCR (Fig. 4A) confirmed the highly enriched expression of the zinc finger factor, Zcchc12, which is also known as Smad-interacting zinc finger protein (Sizn1) and whose known sequence variants are associated with mental retar- dation (Cho et al., 2008b). Zcchc12 is an X-linked gene that has been shown to promote cholinergic transmitter phenotype by stimulating bone morphogenetic protein-dependent regulation of choline acetyltransferase and vesicular acetylcholine transporter genes in basal forebrain cholinergic neurons (Cho et al., 2008a). These known functions raise the possibility that Zcchc12 also regulates serotonergic neuron neurochemical properties. Rnf112 (also known as Zfp179 or Znf179) is thought to encode a zinc finger transcription factor (Seki et al., 1999). We verified Rnf112 enrichment in rostral and caudal 5HT neurons by Taqman RT-PCR (Fig. 4A). The Rnf112 gene maps within the common chromosomal 17p11.2 duplicated region that is responsible for Potocki-Lupski syndrome (PLS) (Kimura et al., 1997). This syndrome is characterized by neurodevelopmental and behavioral phenotypes including anxiety and autism spectrum features (Potocki et al., 2007). We confirmed expression of some other genes exhibiting more modest enrichment in $\mathrm{R}^{+}$and $\mathrm{C}^{+}$. For example, Tox (thymocyte selection-associated high mobility group box) is a gene required for T-cell maturation and is also strongly expressed in the developing cingulate and motor cortex of the E16 mouse brain (Mühlfriedel et al., 2007). We found a 
Table 3. Top genes with enriched expression in $\mathbf{R}^{+}$(cluster II) and $\mathbf{R}^{+} \mathbf{R}^{-}$(cluster III)

\begin{tabular}{|c|c|c|c|}
\hline Affy ID & Fold change & Gene symbol & Gene title \\
\hline \multicolumn{4}{|l|}{$\mathrm{R}^{+}$-enriched genes } \\
\hline 1425804_at & 29.7 & Hmx2 & H6 homeobox 2 \\
\hline 1420444_at & 27.1 & Slc22a3 & Solute carrier family 22 (organic cation transporter), member 3 \\
\hline 1437339_s_at, 1451406_a_at & $8.9,6.1$ & Pcsk5 & Proprotein convertase subtilisin/kexin type 5 \\
\hline 1449031_at & 8.3 & Cited1 & Cbp/p300-interacting transactivator with Glu/Asp-rich C-terminal domain 1 \\
\hline 1452065_at & 7.9 & Vstm2a & V-set and transmembrane domain-containing $2 \mathrm{~A}$ \\
\hline 1456512_at & 7.2 & Pdzrn4 & PDZ domain-containing RING finger 4 \\
\hline 1425083_at & 6.8 & Otor & Otoraplin \\
\hline 1422052_at, 1455365_at & $5.7,4.8$ & Cdh8 & Cadherin 8 \\
\hline 1450047_at & 5.3 & Hs6st2 & Heparan sulfate 6-0-sulfotransferase 2 \\
\hline 1419719_at & 5.1 & Gabrb1 & $\mathrm{GABA}_{\mathrm{A}}$ receptor, subunit $\beta 1$ \\
\hline 1426621_a_at & 4.9 & Ppp2r2b & Protein phosphatase 2 (formerly $2 A$ ), regulatory subunit $B$ (PR 52 ), $\beta$ isoform \\
\hline 1436662_at & 4.5 & Sorcs1 & VPS10 domain receptor protein SORCS 1 \\
\hline 1436137_at & 4.3 & Slc6a17 & Solute carrier family 6 (neurotransmitter transporter), member 17 \\
\hline 1440545_at & 4.2 & ENSMUSG00000075319 & Predicted gene, ENSMUSG00000075319 \\
\hline 1440455_at, 1456609_at & $4.0,3.6$ & Camk2n1 & Calcium/calmodulin-dependent protein kinase II inhibitor 1 \\
\hline 1452728_at & 3.9 & Kirrel3 & Kin of IRRE-like 3 (Drosophila) \\
\hline 1422150_at & 3.8 & $\mathrm{Hmx3}$ & H6 homeobox 3 \\
\hline 1431569_a_at & 3.8 & Lypd1 & Ly6/Plaur domain-containing 1 \\
\hline 1426712_at & 3.8 & Slc6a15 & Solute carrier family 6 (neurotransmitter transporter), member 15 \\
\hline 1423551_at, 1434115_at & $3.8,3.3$ & $\operatorname{Cdh} 13$ & Cadherin 13 \\
\hline 1456778_at & 3.7 & - & - \\
\hline 1449979_a_at & 3.6 & Spock3 & Sparc/osteonectin, cwcv, and kazal-like domains proteoglycan 3 \\
\hline 1440425_at & 3.6 & - & - \\
\hline 1429390_at & 3.5 & Acpl2 & Acid phosphatase-like 2 \\
\hline 1459214_at & 3.4 & - & - \\
\hline 1438729_at & 3.4 & Sox1 & SRY-box-containing gene 1 \\
\hline \multicolumn{4}{|l|}{$\mathrm{R}^{+} \mathrm{R}^{-}$-enriched genes } \\
\hline 1418868_at & 18.3 & En2 & Engrailed 2 \\
\hline 1438009_at & 11.1 & Hist1h2ab/Hist1h2ac & Histone cluster 1 \\
\hline 1437996_s_at, 1455471_at & $8.4,6.6$ & 00012D20Rik & RIKEN CDNA $1500012 \mathrm{D} 20$ gene \\
\hline 1418618_at & 7.2 & En1 & Engrailed 1 \\
\hline 1418666_at & 4.5 & Ptx3 & Pentraxin-related gene \\
\hline 1456127_at & 4.5 & Cnpy1 & Canopy 1 homolog (zebrafish) \\
\hline 1455620_at & 3.6 & EG628779 & Predicted gene, EG628779 \\
\hline 1442558_at & 3.4 & ENSMUSG000000072792 & Predicted gene, ENSMUSG00000072792 \\
\hline 1451888_a_at & 3.0 & $0 \mathrm{dz4}$ & Odd Oz/ten-m homolog 4 (Drosophila) \\
\hline 1447676_x_at, 1425560_a_at & $2.8,2.7$ & S100a16 & S100 calcium-binding protein A16 \\
\hline 1454178_at & 2.6 & 2610027F03Rik & RIKEN CDNA $2610027 F 03$ gene \\
\hline 1434458_at & 2.5 & Fst & Follistatin \\
\hline 1452968_at & 2.4 & Cthrc1 & Collagen triple helix repeat-containing 1 \\
\hline 1451983_at & 2.2 & Irx1 & Iroquois-related homeobox 1 (Drosophila) \\
\hline 1427252_at & 2.1 & Dmrtb1 & DMRT-like family B with proline-rich C-terminal, 1 \\
\hline 1439557_s_at & 2.1 & Ldb2 & LIM domain-binding 2 \\
\hline 1435917_at & 1.9 & 0ciad2 & OCIA domain-containing 2 \\
\hline 1426298_at & 1.9 & Irx2/L0C100045612 & Iroquois-related homeobox 2 (Drosophila) \\
\hline 1436449_at & 1.8 & - & - \\
\hline 1451479_a_at & 1.8 & Tmem53 & Transmembrane protein 53 \\
\hline 1435297_at & 1.8 & Gjd2 & Gap junction protein, $\delta 2$ \\
\hline 1425530_a_at & 1.7 & Stx3 & Syntaxin 3 \\
\hline 1418502_a_at & 1.7 & $0 \times 1$ & 0xidation resistance 1 \\
\hline 1424133_at & 1.5 & Tmem98 & Transmembrane protein 98 \\
\hline
\end{tabular}

3.0-fold enrichment of Tox expression in $\mathrm{R}^{+}$and $\mathrm{C}^{+}$by array analysis and a similar level of enrichment was also detected by Taqman assays (Fig. 4A). RIKEN cDNA 1700042O10RIK, showed a 20 -fold enrichment in $\mathrm{R}^{+} \mathrm{C}^{+}$by array detection and 30 -fold and 150-fold enrichment in $\mathrm{R}^{+}$and $\mathrm{C}^{+}$, respectively, by Taqman RT-PCR (Fig. 4B). Interestingly, 1700042O10RIK encodes a noncoding RNA of unknown function whose gene is embedded in the dopa decarboxylase gene but on opposite strands. This finding raises the intriguing hypothesis that $1700042 \mathrm{O} 10 \mathrm{RIK}$ RNA is a novel regulator of ddc transcription in $5 \mathrm{HT}$ neurons by a cis-antisense mechanism. We also verified ex- pression of other genes whose functions cannot be predicted by homology comparisons. RIKEN cDNA 2010204K13RIK encodes a predicted single transmembrane 83 amino acid protein and was enriched 10 -fold in both $\mathrm{R}^{+}$and $\mathrm{C}^{+}$. In addition, we confirmed the strong expression of EST AW551984 by both Taqman RTPCR (Fig. 4B) and double-label in situ hybridization (Fig. 4C). Confirmation of the 5HT neuron-specific expression of these uncharacterized protein-coding genes suggests novel proteins carry out functions specifically in 5HT neurons. FoxP1, a forkhead domain transcription factor, is required for motoneuron diversity and ultimately the development of spinal cord motor 

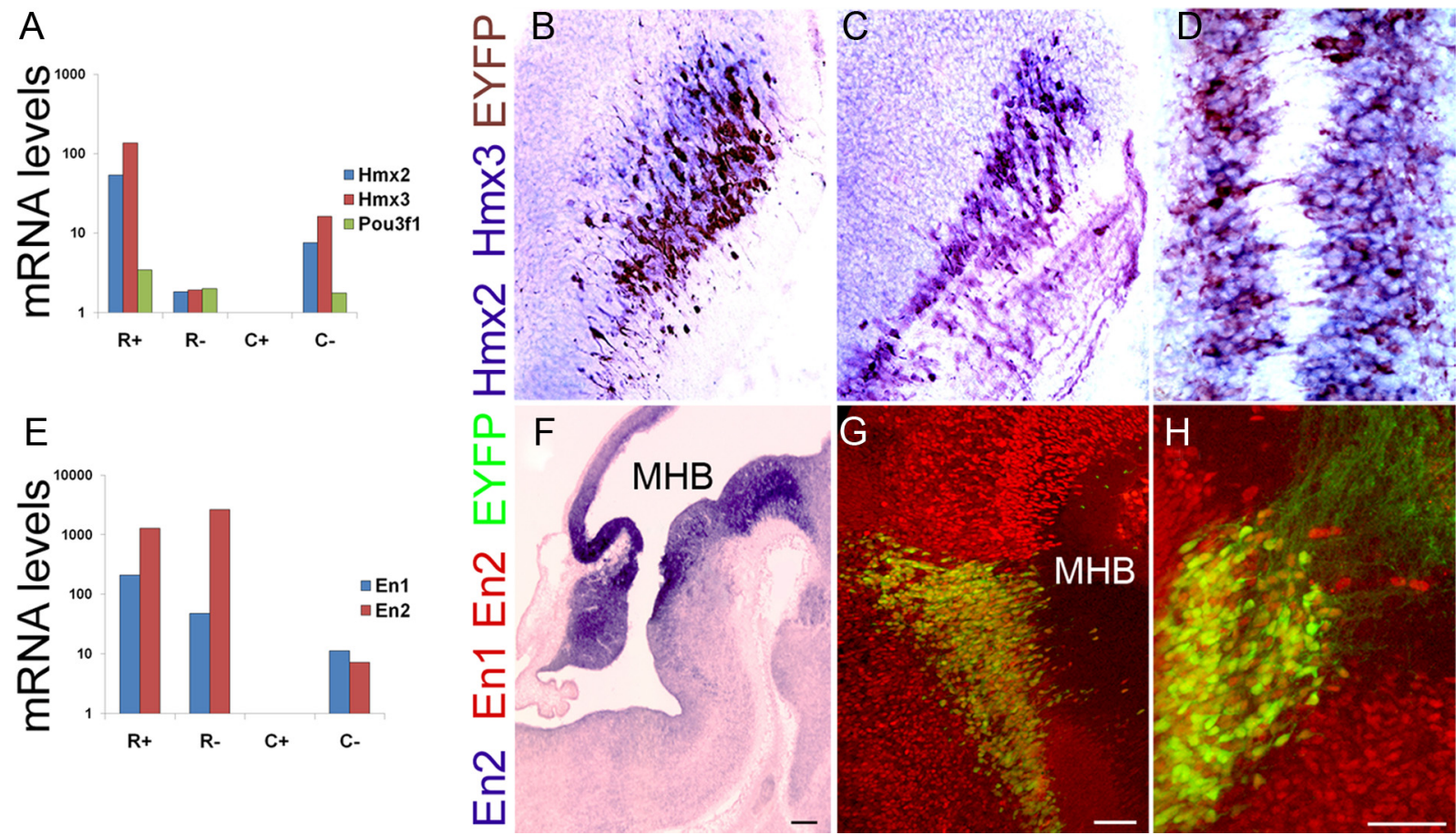

Figure 5. Verification of rostral $5 H T$ neuron-enriched HD gene expression. $A$, Taqman $R T-P C R$ confirmed enriched expression of Hmx2, Hmx3, and Pou3f1 homeodomain genes in rostral $\left(R^{+}\right)$but not caudal $\left(\mathrm{C}^{+}\right)$5HT neurons. $\boldsymbol{B}-\boldsymbol{D}$, Double-label in situ hybridization (blue) and immunohistochemistry for EYFP (brown) confirmed expression of Hmx2 (B) and Hmx3 (C) in E12.5 rostral $5 \mathrm{HT}$ neurons. D, Hmx2 expression was maintained in rostral $5 \mathrm{HT}$ neurons at E16.5. $\boldsymbol{E}$, Taqman RT-PCR verification of enriched En1 and En2 gene expression in E12.5 rostral $5 \mathrm{HT}$ neurons $\left(\mathrm{R}^{+}\right)$as well as non-5HT cells $\left(\mathrm{R}^{-}\right.$and $\mathrm{C}^{-}$) but not caudal $5 \mathrm{HT}$ neurons $\left(\mathrm{C}^{+}\right) \cdot \boldsymbol{F}$, In situ hybridization for En2 at E12.5 shows a broad domain of expression on either side of the MHB. Immunohistochemical staining with a pan-engrailed antibody (red) detected En1 and En2 proteins in EYFP ${ }^{+}$(green) 5 HT neurons in rhombomere 1 at E12.5. G, En1/2 protein expression persisted in rostral $5 \mathrm{HT}$ neurons at E14.5. Scale bars: $\boldsymbol{B}, \boldsymbol{C}, \boldsymbol{G}, 50 \mu \mathrm{m} ; \boldsymbol{D}, \boldsymbol{H}, 100 \mu \mathrm{m} ; \boldsymbol{F}, 500 \mu \mathrm{m}$.

circuitry (Rousso et al., 2008). We found a 2.1-fold enrichment of FoxP1 in $\mathrm{R}^{+}$and $\mathrm{C}^{+}$. Immunohistochemical detection of FoxP1 indicated that FoxP1 protein was expressed by a large number of both rostral and caudal 5HT neurons at E12.5 (Fig. 4D-F). Altogether, the verified highly enriched expression of these genes in $\mathrm{R}^{+}$and $\mathrm{C}^{+}$suggests new candidate regulators of $5 \mathrm{HT}$ neuron development.

\section{Gene ontology and pathway enrichment in 5HT neurons}

The distinct gene expression profiles detected in 5HT neurons versus reference nonserotonergic cell types suggest 5HT neurons may selectively use particular signaling and biological pathways. We used our recently developed parametric approach (Wang et al., 2008) based on mixed linear models to search for enrichment of sets of genes that operate together in a common signaling pathways or are associated with GO categories: molecular function, biological process, and cellular component. We queried gene sets for canonical pathways and gene ontology terms in the MSigDB collection. Because many gene sets were examined, to control for the rate of false-positive findings by chance, we adjusted nominal $p$ values using Bonferroni correction. We identified highly significant enrichment of numerous gene sets for canonical pathways and $\mathrm{GO}$ categories in $\mathrm{R}^{+} \mathrm{C}^{+}$profiles relative to reference $\mathrm{R}^{-} \mathrm{C}^{-}$profiles (Table 2; see Dataset 3, available at www.jneurosci.org as supplemental material), which suggests that 5 HT neurons perform a variety of specialized functions. Enrichment of numerous gene sets associated with peptide processing is consistent with the known peptidergic activity of some $5 \mathrm{HT}$ neurons and further reveals the molecules that may be required for use of these peptides as serotonergic signals. A large number of gene sets associated with ion transport and G-protein-coupled receptor pathways may reflect the complexity of afferent signaling systems regulating 5HT neuron activity and is consistent with the idea that cell surface channels and receptors are a major determinant of cell type heterogeneity in the nervous system (Doyle et al., 2008).

Finally, our analyses identified nine significantly enriched gene sets associated with lipid and specifically sphingolipid (SL) metabolism in $\mathrm{R}^{+}$and $\mathrm{C}^{+}$compared to reference groups $\mathrm{R}^{-}$and $\mathrm{C}^{-}$(Table 2). SLs have been suggested to influence many aspects of nervous system development including neuronal proliferation, differentiation and axonal growth, and synaptic vesicle exocytosis (Colombaioni and Garcia-Gil, 2004; Darios et al., 2009). Ceramide has been shown to promote axonal growth and branching in cultured hippocampal neurons (Schwarz and Futerman, 1997). We speculate that serotonergic enrichment of SL metabolic pathways during the period of $5 \mathrm{HT}$ neuron maturation may be required to support the exuberant and complex axonogenesis and collateralization that must occur for proper development of this transmitter system.

\section{Rostral 5HT neuron transcriptome landscape}

The segregation of several hundred $\mathrm{R}^{+}$or $\mathrm{C}^{+}$expressed genes into four additional clusters (clusters II-IV) suggested previously unrecognized deep molecular heterogeneity in these two groups of embryonic 5HT neurons. We, therefore, examined these clusters individually to identify molecular signatures that distinguish rostral and caudal 5HT neurons.

Cluster II (Table 3 ) is comprised of 94 probe sets corresponding to 84 unique transcripts enriched in $\mathrm{R}^{+}$(supplemental Table S9, available at www.jneurosci.org as supplemental material). This list revealed the highly enriched expression of two genes, 
Table 4. Top genes with enriched expression in $\mathrm{C}^{+}$(cluster IV) and $\mathrm{C}^{+} \mathrm{C}^{-}$(cluster V)

\begin{tabular}{|c|c|c|c|}
\hline Affy ID & Fold change & Gene symbol & Gene title \\
\hline \multicolumn{4}{|l|}{$\mathrm{C}^{+}$-enriched genes } \\
\hline 1441429_at & 20.3 & Irs4 & Insulin receptor substrate 4 \\
\hline 1442724_at & 15.6 & Dlk1 & $\delta$-like 1 homolog (Drosophila) \\
\hline 1455436_at & 13.0 & Diras2 & DIRAS family, GTP-binding RAS-like 2 \\
\hline 1418589_a_at & 11.9 & Mlf1 & Myeloid leukemia factor 1 \\
\hline 1457733_at & 9.7 & - & - \\
\hline 1457635_s_at & 9.6 & $\mathrm{Nr} 3 \mathrm{Cl} 1$ & Nuclear receptor subfamily 3, group C, member 1 \\
\hline 1424250_a_at & 9.3 & Arhgef3 & Rho guanine nucleotide exchange factor (GEF) 3 \\
\hline 1438540_at & 8.8 & Col25a1 & Collagen, type XXV, $\alpha 1$ \\
\hline 1460482_at & 7.7 & 3110047P20Rik & RIKEN CDNA 3110047P20 gene \\
\hline 1449939_s_at & 7.4 & Dlk1 & $\delta$-like 1 homolog (Drosophila) \\
\hline 1445268_at & 6.1 & - & - \\
\hline 1418756_at & 5.6 & Trh & Thyrotropin-releasing hormone \\
\hline 1456096_at & 5.5 & 6430573F11Rik & RIKEN CDNA 6430573F11 gene \\
\hline 1437868_at & 5.3 & BC023892 & cDNA sequence $\mathrm{BC} 023892$ \\
\hline 1441258_at & 5.2 & AF529169 & CDNA sequence AF529169 \\
\hline 1433787_at & 5.2 & Nell1 & NEL-like 1 (chicken) \\
\hline 1423836_at & 5.1 & Zfp503 & Zinc finger protein 503 \\
\hline 1448125_at & 5.0 & Rit2 & Ras-like without CAAX 2 \\
\hline 1427122_at & 4.9 & Copg2as2 & Coatomer protein complex, subunit $\gamma 2$, antisense 2 \\
\hline 1439827_at & 4.9 & Adamts12 & A disintegrin-like and metallopeptidase (reprolysin type) with thrombospondin type 1 motif, 12 \\
\hline 1428765_at & 4.7 & Meg3 & Maternally expressed 3 \\
\hline 1417217_at & 4.6 & Magel2 & Melanoma antigen, family L, 2 \\
\hline 1435513_at & 4.4 & $\mathrm{Htr} 2 \mathrm{C}$ & 5-Hydroxytryptamine (serotonin) receptor $2 \mathrm{C}$ \\
\hline 1449465_at & 4.4 & Reln & Reelin \\
\hline 1427123_s_at & 4.2 & Copg2as2 & Coatomer protein complex, subunit $\gamma 2$, antisense 2 \\
\hline \multicolumn{4}{|l|}{$\mathrm{C}^{+} \mathrm{C}^{-}$-enriched genes } \\
\hline 1418415_at & 68.0 & Hoxb5 & Homeobox B5 \\
\hline 1441070_at, 1429019_s_at & $46.0,5.5$ & Hoxb3 & Homeobox B3 \\
\hline 1458622_at, 1455426_at & $39.7,4.7$ & Hoxa5 & Homeobox A5 \\
\hline 1423756_s_at & 33.8 & Hoxc4 & Homeobox C4 \\
\hline 1449368_at, 1421841_at & $23.1,7.2$ & Hoxd3 & Homeobox D3 \\
\hline 1428429_at, 1452421_at & $19.7,4.2$ & Hoxa3 & Homeobox A3 \\
\hline 1451277_at & 17.6 & Hoxc5 & Homeobox C5 \\
\hline 1439885_at & 16.9 & Hoxb6 & Homeobox B6 \\
\hline 1457966_at & 12.5 & Hoxb4 & Homeobox B4 \\
\hline 1438042_at & 10.9 & Al448005 & Expressed sequence Al448005 \\
\hline 1444543_at & 10.1 & - & - \\
\hline 1440177_at, 1434818_at, 1455299_at & $9.8,8.8,6.9$ & $\operatorname{Ttr}$ & Transthyretin \\
\hline 1460379_at & 8.4 & Hoxb2 & Homeobox B2 \\
\hline 1428026_at & 8.1 & Hoxa4 & Homeobox A4 \\
\hline 1416783_at & 7.7 & Tac1 & Tachykinin 1 \\
\hline 1460214_at & 7.6 & Den & Decorin \\
\hline 1450209_at & 6.9 & Shox2 & Short stature homeobox 2 \\
\hline 1420401_a_at & 6.9 & Hoxa2 & Homeobox A2 \\
\hline 1456229_at & 5.7 & 0610040B09Rik & RIKEN CDNA 0610040B09 gene \\
\hline 1458470_at & 5.4 & A930038C07Rik & RIKEN CDNA A930038C07 gene \\
\hline 1416561_at & 4.9 & Gad1 & Glutamic acid decarboxylase 1 \\
\hline 1430596_s_at & 4.9 & Sorl1 & Sortilin-related receptor, LDLR class A repeats-containing \\
\hline 1460693_a_at & 4.2 & Hoxb7/Hoxb8 & Homeobox B7/homeobox B8 \\
\hline 1451761_at & 3.9 & - & - \\
\hline 1451461_a_at & 3.9 & - & - \\
\hline
\end{tabular}

Hmx2 (Nkx5.2) and Hmx3 (Nkx5.1), encoding related homeodomain proteins in $\mathrm{R}^{+}$with little or no expression detected in $\mathrm{C}^{+}$. Taqman RT-PCR confirmed the enriched expression of both Hmx2 (80-fold) and Hmx3 (120-fold) in $\mathrm{R}^{+}$(Fig. 5A). In situ hybridization double-label immunohistochemistry at E12.5 demonstrated that Hmx2 (Fig. 5B) marked all rostral 5HT neurons, while $\mathrm{Hmx} 3$ expression was observed in a subpopulation of rostral 5HT neurons (Fig. 5C). Hmx2 expression was maintained at E16.5 (Fig. 5D), while Hmx3 transcript was detectable at a lower level at E14.5 (data not shown). The expression of these genes provides a molecular signature of serotonergic neurons in the rostral hindbrain. Verification of Pou3f1, a POU homeodomain transcription factor, indicated enriched expression to a lesser extent than the Hmx genes in $\mathrm{R}^{+}$(Fig. 5A).

Cluster III comprises 27 probe sets that correspond to 25 unique transcripts enriched in both $\mathrm{R}^{+}$and $\mathrm{R}^{-}$cells (Table 3; supplemental Table S10, available at www.jneurosci.org as supplemental material). Of particular interest in this list are the engrailed homeodomain transcription factor genes, En1 and En2, which have been extensively studied for their multiple roles in nervous system development including establishment of the midbrain-hindbrain boundary, cerebellum development, axonal 
guidance, and dopamine neuron development and survival (Joyner, 1996; Simon et al., 2004). Taqman RT-PCR confirmed their enrichment in $\mathrm{R}^{+}$as well as $\mathrm{R}^{-}$and $\mathrm{C}^{-}$reference cell populations but not $\mathrm{C}^{+}$ (Fig. 5E). In situ hybridization for En2 at E12.5 showed a broad domain of expression that spanned both sides of the midhindbrain boundary (MHB) (Fig. 5F). Postmitotic rostral 5HT neurons have migrated from the ventricular zone by E12.5 and were situated in the En2+ region below the MHB. Immunohistochemical detection with a pan-engrailed antibody (Davis et al., 1991) showed strong and persistent expression of En1/En2 proteins in a subset of postmitotic rostral 5HT neurons in rhombomere $1(\mathrm{r} 1)$ at least through E14.5 (Fig. 5G,H). These findings raise the possibility that engrailed genes play cell-autonomous roles in the differentiation and maintenance of rostral 5 HT neurons.

\section{Caudal 5HT neuron}

\section{transcriptome landscape}

We next examined clusters IV and V to identify transcripts enriched in caudal 5HT neurons. Cluster IV comprises 300 probe sets, which correspond to 270 unique transcripts and 29 RIKEN cDNAs enriched in $\mathrm{C}^{+}$neurons (Table 4; supplemental Table S11, available at www. jneurosci.org as supplemental material). We identified several imprinted genes, Dlk1, Meg3, Magel2, and Copg2as2, each with severalfold-enriched expression in $\mathrm{C}^{+}$. However, unlike the Hmx and En genes, whose expression was overwhelmingly enriched in rostral 5HT neurons, these $\mathrm{C}^{+}$enriched genes also showed significant but less enrichment in $\mathrm{R}^{+}$ cells (Dataset 2, available at www.jneurosci.org as supplemental material). These genes are members of three distinct imprinted domains present on different chromosome and thus raise the possibility that stringent regulation of gene dosage is important for proper 5HT neuron development and function. Further examination of our databases revealed an additional 70 probe sets corresponding to 43 unique imprinted genes showing expression in rostral and caudal 5HT neurons (supplemental Table S12, available at www.jneurosci.org as supplemental material). Only three of these, Ancient, Magel2, Ddc, are reported in the Allen Brain Library list of genes with a TPH2-like expression pattern in the adult mouse brain.

Cluster V represents an additional group of serotonergic genes whose expression was enriched in both $\mathrm{C}^{+}$and $\mathrm{C}^{-}$cells. This cluster comprises 146 probe sets, which corresponds to 113 unique genes and 9 RIKEN cDNAs (Table 4; supplemental Table S13, available at www.jneurosci.org as supplemental material). A striking feature of this profile is the numerous Hox paralogues whose expression was enriched in $\mathrm{C}^{+}$and $\mathrm{C}^{-}$up to 70 -fold relative to $\mathrm{R}^{+}$and $\mathrm{R}^{-}$. Our array studies detected highly enriched expression of 14 Hox genes and their cofactors Meis 1 and Meis 2 in $\mathrm{C}^{+}$, whereas there was little or no expression of these Hox genes in $\mathrm{R}^{+}$(Dataset 2, available at www.jneurosci.org as supple- mental material). Hox genes are well known for their early roles in patterning morphological identities of embryonic structures along the anterior-posterior body axis (Pearson et al., 2005), and more recently they have been implicated in repression of serotonergic fate in rhombomere 4 (Pattyn et al., 2003) and specifying spinal motor-neuron pool identity (Dasen et al., 2005). We verified enrichment of Hox3, Hox4, and Hox5 paralogues by Taqman RT-PCR (Fig. 6A-C). Expression of Meis1 and Meis2 (Fig. $6 D-F$ ), HoxC4 (Fig. $6 G-I$ ), and HoxA3 (Fig. $6 J-L$ ) proteins was confirmed by immunohistochemistry in caudal $5 \mathrm{HT}$ neurons. At E12.5, Meis1/2 and HoxA3 expression spanned the caudal hindbrain and marked most caudal 5HT neurons. HoxC4 expression extended from the spinal cord and into the most posterior hindbrain thus marking only subset of caudal $5 \mathrm{HT}$ neurons. The expression of Hox genes was also reported in array studies of differentiated 5HT neurons derived from a rhesus monkey embryonic stem cell line (Bethea et al., 2009). Together, these findings suggest Hox proteins and their cofactors play important roles in the maturation of postmitotic caudal 5HT neurons.

Gene ontology and differential pathway enrichment in rostral and caudal 5HT neurons

We compared gene set enrichment in $\mathrm{R}^{+}$versus $\mathrm{C}^{+}$expression profiles to further explore the potential functional and metabolic differences between rostral and caudal 5HT neurons. Numerous 
Table 5. Gene ontology and pathway enrichment in $\mathrm{R}^{+}$versus $\mathrm{C}^{+}$5HT neurons

\begin{tabular}{|c|c|c|c|}
\hline Code & Gene set name & Size & Bon \\
\hline \multicolumn{4}{|c|}{$\mathrm{R}^{+}$molecular function-enriched gene sets } \\
\hline 346 & Substrate-specific transmembrane transporter activity & $152 / 308$ & 0.02889313 \\
\hline 271 & Protein kinase activity & $129 / 264$ & 0.00560058 \\
\hline 347 & Substrate-specific transporter activity & $167 / 347$ & 0.00245254 \\
\hline 163 & Kinase activity & $156 / 342$ & 0.00065897 \\
\hline 328 & Small GTPase regulator activity & $21 / 64$ & 0.00779472 \\
\hline \multicolumn{4}{|c|}{$\mathrm{C}^{+}$biological process-enriched gene sets } \\
\hline 62 & Calcium ion transport & $15 / 24$ & 0.00074155 \\
\hline 168 & Di-, trivalent inorganic cation transport & $18 / 29$ & 0.00021683 \\
\hline 800 & Transport & $392 / 703$ & 0.00019125 \\
\hline 246 & G-protein-coupled receptor protein signaling pathway & $114 / 290$ & $3.6497 \times 10^{-5}$ \\
\hline \multicolumn{4}{|c|}{$\mathrm{C}^{+}$molecular function-enriched gene sets } \\
\hline 18 & Aminopeptidase activity & $8 / 10$ & 0.00490194 \\
\hline 174 & Lipid kinase activity & $8 / 11$ & 0.03140293 \\
\hline 38 & Calcium channel activity & $19 / 30$ & 0.01250318 \\
\hline 118 & GTPase regulator activity & $77 / 122$ & 0.00713664 \\
\hline 279 & Protein serine threonine kinase activity & $116 / 189$ & $2.405 \times 10^{-5}$ \\
\hline 168 & Ligand-gated channel activity & $17 / 32$ & 0.00144691 \\
\hline 384 & Transmembrane transporter activity & $174 / 338$ & 0.01154298 \\
\hline 188 & Metal ion transmembrane transporter activity & $66 / 131$ & 0.00658676 \\
\hline
\end{tabular}

Bon, Bonferroni-corrected $p$ value.

gene sets were differentially enriched in $\mathrm{R}^{+}$and $\mathrm{C}^{+}$neurons, including those associated with intracellular signaling pathways, GPCR pathways, channel activity, integrin pathways, axon guidance, and ion transport. Gene sets associated with several metabolic pathways were also differentially enriched in either $\mathrm{R}^{+}$or $\mathrm{C}^{+}$, thus further indicating major differences in $\mathrm{R}^{+}$and $\mathrm{C}^{+}$gene expression and further supporting possibility of significant physiological differences in these serotonergic cell types (Table 5, see Dataset 4, available at www.jneurosci.org as supplemental material for complete list).

\section{Discussion}

This study reports the isolation of postmitotic 5HT neurons from the embryonic mouse hindbrain by flow cytometry and the use of these cells to profile 5HT neuron gene expression. Our array studies detected expression of $\sim 9000$ unique gene products in E12.5 5HT neurons with enriched expression of nearly 800 of these genes. The number of unique genes we detected as expressed in 5HT neurons corresponds strikingly well to the $\sim 10,000$ unique genes that are expressed in a single Aplysia $5 \mathrm{HT}$ interneuron. Few of the most highly enriched 5HT expressed genes, however, were common to these two kinds of 5HT neurons (Moroz et al., 2006). We identified 250 genes whose expression was comparably enriched in both rostral and caudal 5HT neurons and therefore these genes represent potential new markers of developing 5HT neurons. Several of these genes encode proteins with well defined functions in other neural and nonneural cell types. We also detected enriched expression of noncoding RNAs and genes encoding potential proteins whose functions are not predictable from primary structure. Furthermore, gene set enrichment analysis identified potential signaling and biological pathways in 5HT neurons that may support specialized functional roles of these cells. Our findings provide an unprecedented knowledge of the expressed genetic architecture of 5HT neurons and continued verification will sharpen our understanding of this architecture.

5HT neurons are anatomically and functionally heterogeneous but the molecular mechanisms that determine these distinctions are obscure because of a lack of comprehensive expression profiling of these cells. Our findings demonstrate deep molecular and biological pathway distinctions between neurons that give rise to the ascending and descending serotonergic subsystems. Previous immunohistochemical studies have reported the differential expression of a small number of genes encoding various neuropeptides, receptors and the transmitters GABA and glutamate in adult 5HT neurons (Chan-Palay et al., 1978; Hökfelt et al., 1978, 2000; Belin et al., 1983; Day et al., 2004; Lacoste et al., 2006). The Allen Institute identified 248 genes with a Tph2-like expression pattern in adults, but it is not known whether these genes are differentially expressed in developing rostral and caudal 5 HT neurons. Here we demonstrate the power of whole-genome profiling of purified embryonic 5HT neurons by identifying $\sim 500$ genes with major expression differences between developing rostral and caudal 5HT neurons. Many of these genes encode various types of transcription factors, although we also detected differential expression of genes encoding ion channels, intracellular signaling factors, and axonal guidance cues. Rostral and caudal 5HT neurons also display differential enrichment of gene sets that suggest different biological pathways operate in these two anatomically defined populations of 5HT neurons. These findings substantiate the concept derived from genetic fate mapping of 5HT progenitors (Jensen et al., 2008) that despite their common neurotransmitter character distinct developmental programs generate $5 \mathrm{HT}$ neurons in the rostral and caudal hindbrain.

The differential expression of numerous homeodomain (HD) genes, including En1, En2, Hmx2, and $\mathrm{Hmx} 3$ in rostral 5HT neurons and several Hox in caudal 5HT neurons raises the possibility that different intrinsic transcriptional cascades comprising different HDs may operate in developing postmitotic 5HT neurons. Hmx2 and Hmx3 are required for inner ear development and differentiation of specific hypothalamic neuronal cell types (Wang et al., 2004) but they have not been investigated for a role in 5HT neuron development. En 1, 2 are required in a redundant manner for $5 \mathrm{HT}$ neuron development (Simon et al., 2005). As En expression was reported to be undetected in 5HT neurons these findings were interpreted as indicating a cell nonautonomous role for En1, 2 in 5HT neuron development. However, more recent intersectional/subtractive genetic cell fate 
mapping studies have demonstrated that a pool of $\mathrm{En}^{+}$progenitors in $\mathrm{r} 1$ give rise to all $5 \mathrm{HT}$ neurons that populate the adult $\mathrm{B} 4$, $\mathrm{B} 6$, and $\mathrm{B} 7$ raphe nuclei as well as some 5HT neurons in the B5 and B8 median raphe and B9 nuclei (Jensen et al., 2008). In addition, our array, RT-qPCR and immunohistochemical verification findings presented here indicated highly enriched expression of En1 and En2 in an anterior subset of postmitotic rostral $5 \mathrm{HT}$ neurons in $\mathrm{r} 1$. Together, these findings strongly suggest that rather than playing a cell nonautonomous role, En $1 / 2$ genes have intrinsic roles in rostral 5HT neurons.

Our array and verification studies showed highly enriched expression of Hmx2 and Hmx3 in rostral 5HT neurons with no detectable expression of these genes in caudal 5HT neurons. Furthermore, Hox expression was detected in caudal 5HT neurons but not in rostral ones. Thus, rostral 5HT neurons can be defined as an $\mathrm{Hmx}^{+}$subtype and caudal $5 \mathrm{HT}$ neurons as a $\mathrm{Hox}^{+}$subtype. Our findings also define two rostral postmitotic 5HT neuron subtypes $\left(\mathrm{Hmx}^{+} \mathrm{En}^{+}\right.$and $\left.\mathrm{Hmx}^{+} \mathrm{En}^{-}\right)$based on the differential expression of En $1 / 2$ hence corroborating evidence (Jensen et al., 2008) for serotonergic heterogeneity even greater than suggested by simple rostral and caudal anatomical distinctions. An important question to address experimentally is whether or not En $1 / 2$ and the other HD expression constitute an HD code that is required in specific subsets of postmitotic 5HT neurons to direct and maintain heterogeneous programs of serotonergic differentiation, cell body migration, axonal trajectories, or electrophysiological properties.

Our transcriptome studies have identified many previously unrecognized serotonergic genes with potential roles in disease pathogenesis. Of particular interest are the cell adhesion genes, Cntnap2, Nrxn1, and Cdh10, which we have shown here to be expressed in 5HT neurons and whose common and rare genetic variants have been associated with autism susceptibility (Arking et al., 2008; Kim et al., 2008; Wang et al., 2009). These genes can now be investigated to determine what role they play in $5 \mathrm{HT}$ neurons and whether their disrupted function results in specific disease endophenotypes. Thus, our databases provide a unique bioinformatics resource to help determine serotonergic expression of genes identified in human psychiatric genome association and linkage studies.

Interestingly, we found expression of 43 different imprinted genes in rostral and caudal 5HT neurons (supplemental Table 12, available at www.jneurosci.org as supplemental material), of which 19 were enriched in 5HT neurons. There are 131 currently known mouse imprinted genes including snoRNAs and miRNAs (http://www.har.mrc.ac.uk/). Many imprinted genes are expressed in the brain and are thought to play critical roles in neurodevelopmental disorders such as autism (Wilkinson et al., 2007). Serotonergic expression of imprinted genes, however, has not been investigated and thus our findings raise the intriguing concept that maternal versus paternal gene expression dosage is important for normal serotonergic function and serotonergic modulation of behavior. An interesting example is Magel2, a paternally imprinted gene that encodes a member of MAGE domain family of proteins (Barker and Salehi, 2002) that is nearly fivefold enriched in $\mathrm{C}^{+}$. Magel2 and necdin, another MAGE domain imprinted gene, are located near one another in the chromosomal 15q11-q13 region, which when deleted from the paternal allele results in Prader-Willi syndrome (PWS) and when deleted from the maternal allele results in Angelman syndrome (Horsthemke and Wagstaff, 2008). Among the many behavioral and physiological defects present in children with PWS are severe respiratory abnormalities including frequent apneas and irregu- lar rhythms (Nixon and Brouillette, 2002). Recent studies in mice have shown that Necdin is also expressed in developing and adult 5HT neurons (Zanella et al., 2008) and as shown here (Dataset 2, available at www.jneurosci.org as supplemental material) at least as early as E12.5. Loss of Necdin function in mice results in defects in 5HT neuron axonal outgrowth and transmitter vesicles (Lee et al., 2005; Zanella et al., 2008). In addition, Necdin ${ }^{-1-}$ mice have respiratory deficits that resemble those in PWS (Ren et al., 2003; Zanella et al., 2008) and is consistent with our finding of severe respiratory deficits in 5HT deficient Pet- $1^{-1-}$ neonates (Erickson et al., 2007). Similarly, Magel $2^{-1-}$ mice have serotonergic deficits (Mercer et al., 2009) and therefore combined loss of function of Necdin and Magel2 in 5HT neurons may contribute to the respiratory deficits seen in PWS. Further support for an important role of Magel2 in 5HT neuron development is the additional behavioral similarities of Pet- $1^{-/-}$and Magel $2^{-1-}$ mice, including increased anxiety in novel environments and maternal behavior defects (Mercer and Wevrick, 2009; Mercer et al., 2009). The latter abnormality is likely to account for the poor survival of neonates born to Magel $2^{-1-}$ dams and is consistent with recent findings from our laboratory using Pet- $1^{-/-}$females (Lerch-Haner et al., 2008) and confirmed with TPH2 nulls (Alenina et al., 2009) that brain 5HT is critical for reproductive success. Finally, the PWS imprinted region contains several other imprinted and nonimprinted genes. Examination of our array database indicates serotonergic expression of additional genes in this region including the imprinted genes, MKRN3, SNRF/ SNRPN, UBE3a, and the biallelically expressed GABRB3 gene. Together, these findings suggest expression of the 15q11-q13 region may play an important role in 5HT neuron development and its altered dosage in these cells may contribute to neurodevelopmental disorders.

In conclusion, we have identified numerous potential new determinants of 5HT neuron development and function including several homeodomain-encoding genes whose differential expression offers a molecular classification of 5HT neuron subtypes. Our findings provide a wealth of new knowledge and experimentally testable hypotheses about the genetic networks that generate serotonin neuron subtypes and the potential roles of serotonergic genes in disease pathogenesis.

\section{References}

Alenina N, Kikic D, Todiras M, Mosienko V, Qadri F, Plehm R, Boyé P, Vilianovitch L, Sohr R, Tenner K, Hörtnagl H, Bader M (2009) Growth retardation and altered autonomic control in mice lacking brain serotonin. Proc Natl Acad Sci U S A 106:10332-10337.

Ansorge MS, Hen R, Gingrich JA (2007) Neurodevelopmental origins of depressive disorders. Curr Opin Pharmacol 7:8-17.

Arking DE, Cutler DJ, Brune CW, Teslovich TM, West K, Ikeda M, Rea A, Guy M, Lin S, Cook EH, Chakravarti A (2008) A common genetic variant in the neurexin superfamily member CNTNAP2 increases familial risk of autism. Am J Hum Genet 82:160-164.

Barker PA, Salehi A (2002) The MAGE proteins: emerging roles in cell cycle progression, apoptosis, and neurogenetic disease. J Neurosci Res 67:705-712.

Beck SG, Pan YZ, Akanwa AC, Kirby LG (2004) Median and dorsal raphe neurons are not electrophysiologically identical. J Neurophysiol 91:994-1005

Belin MF, Nanopoulos D, Didier M, Aguera M, Steinbusch H, Verhofstad A, Maitre M, Pujol JF (1983) Immunohistochemical evidence for the presence of gamma-aminobutyric acid and serotonin in one nerve cell. A study on the raphe nuclei of the rat using antibodies to glutamate decarboxylase and serotonin. Brain Res 275:329-339.

Benjamini Y, Hochberg Y (1995) Controlling the false discovery rate: a practical and powerful approach to multiple testing. J R Stat Soc 57:289-300. 
Bethea CL, Reddy AP, Pedersen D, Tokuyama Y (2009) Expression profile of differentiating serotonin neurons derived from rhesus embryonic stem cells and comparison to adult serotonin neurons. Gene Expr Patterns 9:94-108.

Cahoy JD, Emery B, Kaushal A, Foo LC, Zamanian JL, Christopherson KS, Xing Y, Lubischer JL, Krieg PA, Krupenko SA, Thompson WJ, Barres BA (2008) A transcriptome database for astrocytes, neurons, and oligodendrocytes: a new resource for understanding brain development and function. J Neurosci 28:264-278.

Chan-Palay V, Jonsson G, Palay SL (1978) Serotonin and substance P coexist in neurons of the rat's central nervous system. Proc Natl Acad Sci U S A 75:1582-1586.

Cho G, Lim Y, Zand D, Golden JA (2008a) Sizn1 is a novel protein that functions as a transcriptional coactivator of bone morphogenic protein signaling. Mol Cell Biol 28:1565-1572.

Cho G, Bhat SS, Gao J, Collins JS, Rogers RC, Simensen RJ, Schwartz CE, Golden JA, Srivastava AK (2008b) Evidence that SIZN1 is a candidate X-linked mental retardation gene. Am J Med Genet A 146A:2644-2650.

Colombaioni L, Garcia-Gil M (2004) Sphingolipid metabolites in neural signalling and function. Brain Res Brain Res Rev 46:328-355.

Darios F, Wasser C, Shakirzyanova A, Giniatullin A, Goodman K, MunozBravo JL, Raingo J, Jorgacevski J, Kreft M, Zorec R, Rosa JM, Gandia L, Gutiérrez LM, Binz T, Giniatullin R, Kavalali ET, Davletov B (2009) Sphingosine facilitates SNARE complex assembly and activates synaptic vesicle exocytosis. Neuron 62:683-694.

Dasen JS, Tice BC, Brenner-Morton S, Jessell TM (2005) A Hox regulatory network establishes motor neuron pool identity and target-muscle connectivity. Cell 123:477-491.

Davis CA, Holmyard DP, Millen KJ, Joyner AL (1991) Examining pattern formation in mouse, chicken and frog embryos with an En-specific antiserum. Development 111:287-298.

Day HE, Greenwood BN, Hammack SE, Watkins LR, Fleshner M, Maier SF, Campeau S (2004) Differential expression of 5HT-1A, alpha 1b adrenergic, CRF-R1, and CRF-R2 receptor mRNA in serotonergic, gammaaminobutyric acidergic, and catecholaminergic cells of the rat dorsal raphe nucleus. J Comp Neurol 474:364-378.

Doyle JP, Dougherty JD, Heiman M, Schmidt EF, Stevens TR, Ma G, Bupp S, Shrestha P, Shah RD, Doughty ML, Gong S, Greengard P, Heintz N (2008) Application of a translational profiling approach for the comparative analysis of CNS cell types. Cell 135:749-762.

Eisen MB, Spellman PT, Brown PO, Botstein D (1998) Cluster analysis and display of genome-wide expression patterns. Proc Natl Acad Sci U S A 95:14863-14868.

Erickson JT, Shafer G, Rossetti MD, Wilson CG, Deneris ES (2007) Arrest of $5 \mathrm{HT}$ neuron differentiation delays respiratory maturation and impairs neonatal homeostatic responses to environmental challenges. Respir Physiol Neurobiol 159:85-101.

Gargaglioni LH, Bícegoa KC, Branco LG (2008) Brain monoaminergic neurons and ventilatory control in vertebrates. Respir Physiol Neurobiol 164:112-122.

Hendricks T, Francis N, Fyodorov D, Deneris ES (1999) The ETS domain factor Pet-1 is an early and precise marker of central 5-HT neurons and interacts with a conserved element in serotonergic genes. J Neurosci 19:10348-10356.

Hendricks TJ, Fyodorov DV, Wegman LJ, Lelutiu NB, Pehek EA, Yamamoto B, Silver J, Weeber EJ, Sweatt JD, Deneris ES (2003) Pet-1 ETS gene plays a critical role in 5-HT neuron development and is required for normal anxiety-like and aggressive behavior. Neuron 37:233-247.

Hodges MR, Tattersall GJ, Harris MB, McEvoy SD, Richerson DN, Deneris ES, Johnson RL, Chen ZF, Richerson GB (2008) Defects in breathing and thermoregulation in mice with near-complete absence of central serotonin neurons. J Neurosci 28:2495-2505.

Hökfelt T, Ljungdahl A, Steinbusch H, Verhofstad A, Nilsson G, Brodin E, Pernow B, Goldstein M (1978) Immunohistochemical evidence of substance P-like immunoreactivity in some 5-hydroxytryptaminecontaining neurons in the rat central nervous system. Neuroscience 3:517-538.

Hökfelt T, Arvidsson U, Cullheim S, Millhorn D, Nicholas AP, Pieribone V, Seroogy K, Ulfhake B (2000) Multiple messengers in descending serotonin neurons: localization and functional implications. J Chem Neuroanat $18: 75-86$
Holmes A (2008) Genetic variation in cortico-amygdala serotonin function and risk for stress-related disease. Neurosci Biobehav Rev 32:1293-1314.

Horsthemke B, Wagstaff J (2008) Mechanisms of imprinting of the PraderWilli/Angelman region. Am J Med Genet A 146A:2041-2052.

Jacob J, Ferri AL, Milton C, Prin F, Pla P, Lin W, Gavalas A, Ang SL, Briscoe J (2007) Transcriptional repression coordinates the temporal switch from motor to serotonergic neurogenesis. Nat Neurosci 10:1433-1439.

Jensen P, Farago AF, Awatramani RB, Scott MM, Deneris ES, Dymecki SM (2008) Redefining the serotonergic system by genetic lineage. Nat Neurosci 11:417-419.

Joyner AL (1996) Engrailed, Wnt and Pax genes regulate midbrain-hindbrain development. Trends Genet 12:15-20.

Kim HG, Kishikawa S, Higgins AW, Seong IS, Donovan DJ, Shen Y, Lally E, Weiss LA, Najm J, Kutsche K, Descartes M, Holt L, Braddock S, Troxell R, Kaplan L, Volkmar F, Klin A, Tsatsanis K, Harris DJ, Noens I, et al. (2008) Disruption of neurexin 1 associated with autism spectrum disorder. Am J Hum Genet 82:199-207.

Kimura T, Arakawa Y, Inoue S, Fukushima Y, Kondo I, Koyama K, Hosoi T, Orimo A, Muramatsu M, Nakamura Y, Abe T, Inazawa J (1997) The brain finger protein gene (ZNF179), a member of the RING finger family, maps within the Smith-Magenis syndrome region at 17p11.2. Am J Med Genet 69:320-324.

Kocsis B, Varga V, Dahan L, Sik A (2006) Serotonergic neuron diversity: identification of raphe neurons with discharges time-locked to the hippocampal theta rhythm. Proc Natl Acad Sci U S A 103:1059-1064.

Lacoste B, Riad M, Descarries L (2006) Immunocytochemical evidence for the existence of substance $\mathrm{P}$ receptor (NK1) in serotonin neurons of rat and mouse dorsal raphe nucleus. Eur J Neurosci 23:2947-2958.

Lee S, Walker CL, Karten B, Kuny SL, Tennese AA, O'Neill MA, Wevrick R (2005) Essential role for the Prader-Willi syndrome protein necdin in axonal outgrowth. Hum Mol Genet 14:627-637.

Le François B, Czesak M, Steubl D, Albert PR (2008) Transcriptional regulation at a HTR1A polymorphism associated with mental illness. Neuropharmacology 55:977-985.

Leonardo ED, Hen R (2006) Genetics of affective and anxiety disorders. Annu Rev Psychol 57:117-137.

Lerch-Haner JK, Frierson D, Crawford LK, Beck SG, Deneris ES (2008) Serotonergic transcriptional programming determines maternal behavior and offspring survival. Nat Neurosci 11:1001-1003.

Lillesaar C, Tannhäuser B, Stigloher C, Kremmer E, Bally-Cuif L (2007) The serotonergic phenotype is acquired by converging genetic mechanisms within the zebrafish central nervous system. Dev Dyn 236:1072-1084.

Lucki I (1998) The spectrum of behaviors influenced by serotonin. Biol Psychiatry 44:151-162.

Mason P (2001) Contributions of the medullary raphe and ventromedial reticular region to pain modulation and other homeostatic functions. Annu Rev Neurosci 24:737-777.

Mercer RE, Wevrick R (2009) Loss of magel2, a candidate gene for features of Prader-Willi syndrome, impairs reproductive function in mice. PLoS ONE 4:e4291.

Mercer RE, Kwolek EM, Bischof JM, van Eede M, Henkelman RM, Wevrick R (2009) Regionally reduced brain volume, altered serotonin neurochemistry, and abnormal behavior in mice null for the circadian rhythm output gene Magel2. Am J Med Genet B Neuropsychiatr Genet 150B:1085-1099.

Moroz LL, Edwards JR, Puthanveettil SV, Kohn AB, Ha T, Heyland A, Knudsen B, Sahni A, Yu F, Liu L, Jezzini S, Lovell P, Iannucculli W, Chen M, Nguyen T, Sheng H, Shaw R, Kalachikov S, Panchin YV, Farmerie W, et al. (2006) Neuronal transcriptome of Aplysia: neuronal compartments and circuitry. Cell 127:1453-1467.

Mühlfriedel S, Kirsch F, Gruss P, Chowdhury K, Stoykova A (2007) Novel genes differentially expressed in cortical regions during late neurogenesis. Eur J Neurosci 26:33-50.

Ng L, Bernard A, Lau C, Overly CC, Dong HW, Kuan C, Pathak S, Sunkin SM, Dang C, Bohland JW, Bokil H, Mitra PP, Puelles L, Hohmann J, Anderson DJ, Lein ES, Jones AR, Hawrylycz M (2009) An anatomic gene expression atlas of the adult mouse brain. Nat Neurosci 12:356-362.

Nixon GM, Brouillette RT (2002) Sleep and breathing in Prader-Willi syndrome. Pediatr Pulmonol 34:209-217.

Pattyn A, Vallstedt A, Dias JM, Samad OA, Krumlauf R, Rijli FM, Brunet JF, Ericson J (2003) Coordinated temporal and spatial control of motor neuron and serotonergic neuron generation from a common pool of CNS progenitors. Genes Dev 17:729-737. 
Pearson JC, Lemons D, McGinnis W (2005) Modulating Hox gene functions during animal body patterning. Nat Rev Genet 6:893-904.

Potocki L, Bi W, Treadwell-Deering D, Carvalho CM, Eifert A, Friedman EM, Glaze D, Krull K, Lee JA, Lewis RA, Mendoza-Londono R, RobbinsFurman P, Shaw C, Shi X, Weissenberger G, Withers M, Yatsenko SA, Zackai EH, Stankiewicz P, Lupski JR (2007) Characterization of Potocki-Lupski syndrome $(\operatorname{dup}(17)(\mathrm{p} 11.2 \mathrm{p} 11.2))$ and delineation of a dosage-sensitive critical interval that can convey an autism phenotype. Am J Hum Genet 80:633-649.

Prasad HC, Zhu CB, McCauley JL, Samuvel DJ, Ramamoorthy S, Shelton RC, Hewlett WA, Sutcliffe JS, Blakely RD (2005) Human serotonin transporter variants display altered sensitivity to protein kinase $\mathrm{G}$ and p38 mitogen-activated protein kinase. Proc Natl Acad Sci USA 102: $11545-11550$

Reimers M, Carey VJ (2006) Bioconductor: an open source framework for bioinformatics and computational biology. Methods Enzymol 411:119134.

Ren J, Lee S, Pagliardini S, Gérard M, Stewart CL, Greer JJ, Wevrick R (2003) Absence of Ndn, encoding the Prader-Willi syndrome-deleted gene necdin, results in congenital deficiency of central respiratory drive in neonatal mice. J Neurosci 23:1569-1573.

Rousso DL, Gaber ZB, Wellik D, Morrisey EE, Novitch BG (2008) Coordinated actions of the forkhead protein Foxp1 and Hox proteins in the columnar organization of spinal motor neurons. Neuron 59:226-240.

Schwarz A, Futerman AH (1997) Distinct roles for ceramide and glucosylceramide at different stages of neuronal growth. J Neurosci 17:2929_ 2938.

Scott MM, Wylie CJ, Lerch JK, Murphy R, Lobur K, Herlitze S, Jiang W, Conlon RA, Strowbridge BW, Deneris ES (2005) A genetic approach to access serotonin neurons for in vivo and in vitro studies. Proc Natl Acad Sci U S A 102:16472-16477.

Seki N, Hattori A, Muramatsu M, Saito T (1999) cDNA cloning of a human brain finger protein, BFP/ZNF179, a member of the RING finger protein family. DNA Res 6:353-356.

Simon HH, Thuret S, Alberi L (2004) Midbrain dopaminergic neurons: control of their cell fate by the engrailed transcription factors. Cell Tissue Res 318:53-61.

Simon HH, Scholz C, O'Leary DD (2005) Engrailed genes control develop- mental fate of serotonergic and noradrenergic neurons in mid- and hindbrain in a gene dose-dependent manner. Mol Cell Neurosci 28:96-105.

Smyth GK (2005) Limma: linear models for microarray data. Bioinformatics and computational biology solutions using $\mathrm{R}$ and Bioconductor (Gentleman R, Carey V, Dudoit S, Irizarry R, Huber W, eds), pp 397-420. New York: Springer.

Sodhi MS, Sanders-Bush E (2004) Serotonin and brain development. Int Rev Neurobiol 59:111-174.

Sugino K, Hempel CM, Miller MN, Hattox AM, Shapiro P, Wu C, Huang ZJ, Nelson SB (2006) Molecular taxonomy of major neuronal classes in the adult mouse forebrain. Nat Neurosci 9:99-107.

Wang K, Zhang H, Ma D, Bucan M, Glessner JT, Abrahams BS, Salyakina D, Imielinski M, Bradfield JP, Sleiman PM, Kim CE, Hou C, Frackelton E, Chiavacci R, Takahashi N, Sakurai T, Rappaport E, Lajonchere CM, Munson J, Estes A, et al. (2009) Common genetic variants on 5p14.1 associate with autism spectrum disorders. Nature 459:528-533.

Wang L, Zhang B, Wolfinger RD, Chen X (2008) An integrated approach for the analysis of biological pathways using mixed models. PLoS Genet 4:e1000115

Wang W, Grimmer JF, Van De Water TR, Lufkin T (2004) Hmx2 and Hmx3 homeobox genes direct development of the murine inner ear and hypothalamus and can be functionally replaced by Drosophila Hmx. Dev Cell 7:439-453.

Wilkinson LS, Davies W, Isles AR (2007) Genomic imprinting effects on brain development and function. Nat Rev Neurosci 8:832-843.

Ye W, Shimamura K, Rubenstein JLR, Hynes MA, Rosenthal A (1998) FGF and Shh signals control dopaminergic and serotonergic cell fate in the anterior neural plate. Cell 93:755-766.

Zanella S, Watrin F, Mebarek S, Marly F, Roussel M, Gire C, Diene G, Tauber M, Muscatelli F, Hilaire G (2008) Necdin plays a role in the serotonergic modulation of the mouse respiratory network: implication for PraderWilli syndrome. J Neurosci 28:1745-1755.

Zhao ZQ, Chiechio S, Sun YG, Zhang KH, Zhao CS, Scott M, Johnson RL, Deneris ES, Renner KJ, Gereau RW 4th, Chen ZF (2007) Mice lacking central serotonergic neurons show enhanced inflammatory pain and an impaired analgesic response to antidepressant drugs. J Neurosci 27:60456053. 